\title{
Effect of Combined Conductive Polymer Binder on the Electrochemical Performance of Electrode Materials for Lithium-Ion Batteries
}

\author{
Svetlana N. Eliseeva, Mikhail A. Kamenskii, Elena G. Tolstopyatova $₫$ and \\ Veniamin V. Kondratiev * \\ Institute of Chemistry, Saint Petersburg State University, 7/9 Universitetskaya nab, 199034 Saint Petersburg, \\ Russia; svetlana.eliseeva@spbu.ru (S.N.E.); kamenskymisha@yandex.ru (M.A.K.); \\ e.tolstopyatova@spbu.ru (E.G.T.) \\ * Correspondence: v.kondratev@spbu.ru
}

Received: 25 March 2020; Accepted: 27 April 2020; Published: 1 May 2020

\begin{abstract}
The electrodes of lithium-ion batteries (LIBs) are multicomponent systems and their electrochemical properties are influenced by each component, therefore the composition of electrodes should be properly balanced. At the beginning of lithium-ion battery research, most attention was paid to the nature, size, and morphology peculiarities of inorganic active components as the main components which determine the functional properties of electrode materials. Over the past decade, considerable attention has been paid to development of new binders, as the binders have shown great effect on the electrochemical performance of electrodes in LIBs. The study of new conductive binders, in particular water-based binders with enhanced electronic and ionic conductivity, has become a trend in the development of new electrode materials, especially the conversion/alloying-type anodes. This mini-review provides a summary on the progress of current research of the effects of binders on the electrochemical properties of intercalation electrodes, with particular attention to the mechanisms of binder effects. The comparative analysis of effects of three different binders (PEDOT:PSS/CMC, CMC, and PVDF) for a number of oxide-based and phosphate-based positive and negative electrodes for lithium-ion batteries was performed based on literature and our own published research data. It reveals that the combined PEDOT:PSS/CMC binder can be considered as a versatile component of lithium-ion battery electrode materials (for both positive and negative electrodes), effective in the wide range of electrode potentials.
\end{abstract}

Keywords: lithium-ion batteries; conductive binder; poly-3,4-ethylenedioxythiophene:polystyrene sulfonate; carboxymethylcellulose; electrochemical performance

\section{Introduction}

It is well known that electrodes of lithium-ion batteries (LIBs) are multicomponent systems, consisting of active material and other components such as conductive additives and binder. Hence, we deal with so-called composite micro-heterogeneous electrodes, where active component is in mixture with others. The properties of such multicomponent electrode materials are dependent on all components, which influence each other and therefore should be properly balanced. Conductive additives (typically up to $10 \mathrm{wt}$. \% carbon black) are necessary to ensure high electrical conductivity of the LIB electrode because the inherent electronic conductivity of inorganic electrode materials is very low. A polymer binder is commonly required to bind active material and conductive additive together and support good contact between particles and with current collector, the proper structure of electrodes, and their mechanical integrity [1-4]. 
At the beginning of lithium-ion battery research, most attention was paid to the nature, size $[5,6]$ and morphology peculiarities of inorganic active components as main components of electrode materials, which determine the functional properties of battery material. Less attention was paid to such components of electrodes as binder and conductive additive [1,3,4].

To enhance the electrical conductivity of electroactive materials, different types of carbon coatings have been suggested as surface modifiers of electroactive grains [7-23]. For the same purpose, different conducting polymers (polypyrrole [24-28], polyaniline [25,29-31], polythiophene [32], PEDOT [33-35], and PEDOT:PSS [36,37]) have also been used as surface modifiers or coatings of active grains wherein PVDF or Teflon (PTFE) were usually used as binders. In the works [33,35], two-component electrodes (electroactive grains with PEDOT) are studied.

Polyvinylidene fluoride (PVDF) for a long time has been the most widely used binder for LIB electrodes, in both research and industrial applications, despite its well-known drawbacks such as limited binding strength due to the lack of chemical bonds with electroactive materials, low electronic and lithium-ion conductivity, insufficient flexibility, and toxicity due to the necessity to use the toxic and flammable organic solvent, $\mathrm{N}$-methyl pyrrolidone (NMP), for the electrode fabrication $[4,15,28,38-41]$.

Over the last decade, the chemical nature of binder has also been recognized as an important factor determining the electrochemical performance of Li-ion batteries, along with other components of electrode material $[4,42]$. The type and amount of binder not only affect the mechanical integrity of electrode material, but to a great extent control the electronic and ionic conductivity of inter-granular space of composite electrodes, wettability of carbon, and active material grains, thus influencing the functional characteristics of electrodes $[1,4,43]$.

In recent years, the study of new conductive binder materials with electronic and ionic conductivity has become a trend in the development of new electrode materials. Therefore, many efforts have been devoted to the search of new compositions of electrode materials, in particular the nature and ratios of conductive and binding components and effective combination of the properties of these additives.

As a result, carboxymethyl cellulose (CMC) has recently been recognized as a promising binder for practical application in energy storage systems and has obtained the status of a conventionally applicable component of commercial LIBs. It is especially widely considered as good replacement for conventional PVDF binder in anode materials, such as graphite electrodes [44,45] and alloying electrodes ( $\mathrm{Si}, \mathrm{Sn}$, and some others), where large volume changes during cycling are the major limitations [46-48].

Besides CMC, several other aqueous binders based on various biopolymers, for instance, different polysaccharides, such as alginates [49,50] and chitosans [51,52], and conducting polymers have been proposed as alternatives to PVDF. These new binders allow increasing the electronic and ionic conductivity of electrodes, as well as integrity of material and stability for prolonged cycling [3,4]. Among conducting polymers, commercial PEDOT:PSS dispersion was tested as a novel binder possessing the functions of both binding and conductive additive [53-55]. As in the case of surface modification of active grains, the use of PEDOT:PSS as a binder leads to the enhancement of electrochemical performance. The works in [53-55] are of particular interest due to simplicity of electrode fabrication procedure, although proposed solutions can hardly be considered practical on industrial scale, allowing only thin coatings due to insufficient electrode layer integrity.

Thus, until now, three main categories of works with use of PEDOT:PSS as component of LIB materials have been published. The first category considers PEDOT:PSS as an additive which allows replacement of carbon additives in LIB; the second one considers PEDOT:PSS as an active grain modifier for fabrication of sophisticated structures such as core-shell structures, which are then used in LIB in conventional compositions with PVDF binder; and the third one considers PEDOT:PSS as a bifunctional additive, acting as a binder and conductive component of electrode materials for LIB. The number of papers discussing PEDOT:PSS as a bifunctional component of LIB materials, as both a single component and in combination with some other polymers, is very limited. 
It was shown later that conducting polymers as binder components also enhance material conductivity and form a protective layer on the grains of active material, which suppresses its interaction with the electrolyte and prevents its dissolution or degradation of electrolyte [56,57]. While PVDF is a polymer with rigid structure, which makes it unsuitable for active materials with significant volume changes, flexible conducting polymers maintain good electrical contact between the grains of the active material undergoing continuous expansion and contraction of the lattice during lithiation-delithiation, thus improving cycling stability and rate capability of the material.

Recently, we proposed the combined conductive polymer binder, based on the balanced ratio of PEDOT:PSS and carboxymethyl cellulose (CMC) polymers, which possesses both functions of strong binder and electrical conductor. Although PEDOT:PSS can be used as a sole binder, and CMC is one of the most used aqueous binders [47,58-63], it turns out that their combination has a number of advantages. PEDOT:PSS is a p-doped intrinsically conducting polymer with good conductivity, and the range of its electrochemical activity and stability exceeds the working potential window for studied cathode and anode materials, but its binding function is not sufficient. CMC, besides its binding properties, is an ionic conductor. Due to synergetic combination of their properties, the mixture of PEDOT:PSS and CMC turned out to be an effective binder for a number of high-performance electrode materials for lithium-ion batteries [56,64-69].

As far as we know, the application of PEDOT:PSS/CMC binder was suggested for the first time in [70], but this binder was used in huge mass fraction (20 wt. \%) and was designed to solve a totally different problem - to suppress the mechanical cracking of Si electrodes, where charge-discharge processes result in high volume changes.

Our research on application of combined PEDOT:PSS/CMC binder for electrode materials is focused not only on the change of target electrode material from Si to other cathode and anode materials for LIB, but its main focus is on the solution of other problems: balanced electronic and ionic conductivity of binder, suppression of material interaction with electrolytes without blocking of electrode grains, optimization of amount of binder, and lowering binder content to $4 \mathrm{wt}$. \% in electrode material.

Here, in this mini-review, we restrict ourselves mainly to the discussion of the effects of three different binders (PEDOT:PSS/CMC, CMC, and PVDF) on oxide-based and phosphate-based positive and negative electrodes for lithium-ion batteries ( $\mathrm{LiFePO}_{4}(\mathrm{LFP}), \mathrm{LiFe}_{0.4} \mathrm{Mn}_{0.6} \mathrm{PO}_{4}(\mathrm{LFMP}), \mathrm{LiMn}_{2} \mathrm{O}_{4}$ (LMO), and $\mathrm{Li}_{4} \mathrm{Ti}_{5} \mathrm{O}_{12}$ (LTO)). It allows us to present the combined PEDOT:PSS/CMC binder as a versatile component of lithium-ion battery electrode materials, effective in the wide range of electrode potentials. The basis of our review are the results of systematical study of the effect of PEDOT:PSS/CMC, $\mathrm{CMC}$, and PVDF binders on the electrochemical performance of a selection of commercially available cathode and anode materials, that are widely used in practice. For these active materials, we compare the electrochemical properties of the electrodes of similar composition, fabricated using PEDOT:PSS/CMC, $\mathrm{CMC}$, and PVDF binders.

The thorough literature survey shows that comparative studies that have been performed with the abovementioned binders for the same initial active materials are rarely reported. It should be emphasized that this approach to comparison is the most objective because it is well known that the grain size and structure, carbon or polymer coatings, thickness of electrode layers, etc. play an important role in determining functional parameters.

The literature data and our own results of comparative studies allow concluding that the electrodes with the proposed optimized PEDOT:PSS/CMC binder composition have superior properties in comparison with PVDF-bound electrodes, in particular increased specific capacity, good capacity retention, and C-rate capability. In the case of CMC-bound electrodes, the values of specific capacities at low current densities were slightly worse or comparable with those of PEDOT:PSS/CMC-bound electrodes, whereas both the high C-rate capability and the long-term cycling stability of PEDOT:PSS/CMC-bound electrodes were markedly superior.

The benefits of using combined conductive PEDOT:PSS/CMC binder compared to PVDF and CMC binders are as follows: (i) more complete utilization of active material and increase of specific 
capacity due to enhancement of ionic and electronic conductivity of the electrode; (ii) enhancement of the cycling stability of electrodes resulting from lower degradation of electroactive material grains with a polymeric protective layer; and (iii) green water-based material preparation route in substitution for processing of a fluorine-containing polymer in toxic volatile solvent (for PVDF).

In this mini-review, we demonstrate the versatility of combined PEDOT:PSS/CMC binder for both cathode and anode materials and discuss the results summarizing the effect of conducting polymer binders on the electrochemical performance of cathode $\left(\mathrm{LiFePO}_{4}(\mathrm{LFP}), \mathrm{LiFe}_{0.4} \mathrm{Mn}_{0.6} \mathrm{PO}_{4}\right.$ (LFMP), and $\mathrm{LiMn}_{2} \mathrm{O}_{4}(\mathrm{LMO})$ ) and anode $\left(\mathrm{Li}_{4} \mathrm{Ti}_{5} \mathrm{O}_{12}\right.$ (LTO)) materials with optimized amount of PEDOT:PSS/CMC binder and provide mechanistic insights on the binder effects observed.

\section{Materials and Methods}

Carbon-coated C-LiFePO 4 (LFP) was from Phostech Lithium Inc. (St-Bruno-De-Montarville, Canada). Battery-grade $\mathrm{LiFe}_{0.4} \mathrm{Mn}_{0.6} \mathrm{PO}_{4}$ (LFMP) was from Clariant Producte $\mathrm{GmbH}$ (Munich, Germany). Battery-grade $\mathrm{LiMn}_{2} \mathrm{O}_{4}$ (LMO) powder was from MTI Corp. (Richmond, CA, USA). $\mathrm{Li}_{4} \mathrm{Ti}_{5} \mathrm{O}_{12}$ (LTO) powder (mean grain size $<200 \mathrm{~nm}$ ) was from Aldrich. Conducting carbon black "Super $\mathrm{P}^{\prime}(\mathrm{C})$ was from Timcal Inc. (Willebroek, Belgium). The $1.3 \mathrm{wt}$. \% poly-3,4-ethylenedioxythiophene:polystyrene sulfonate (PEDOT:PSS) dispersion, polyvinylidene fluoride (PVDF), and N-methylpyrrolidone (NMP) were from Aldrich. Carboxymethyl cellulose (CMC) (MW 400.000 DS 0.98) was from MTI Corp. (Richmond, CA, USA). All reagents were used as received, except for electroactive materials, which were vacuum dried for $2-4 \mathrm{~h}$ at $130^{\circ} \mathrm{C}$ prior to use.

Series of electrodes with different active materials, containing two types of binders (PEDOT:PSS/CMC or PVDF) and carbon black additive were prepared and tested. The ratios of components are given in Table 1. CMC was pre-soaked in PEDOT:PSS dispersion. PVDF binder was prepared as described elsewhere. The slurry components were mechanically mixed together for $1 \mathrm{~h}$ until homogeneous. The prepared electrode slurry was uniformly coated onto $\mathrm{Al}$ foil with doctor blade. PEDOT:PSS/CMC-bound electrode foils were vacuum dried at $80^{\circ} \mathrm{C}$ and PVDF-bound at $120^{\circ} \mathrm{C}$ for $6 \mathrm{~h}$. The electrode foils were then roll-pressed and cut into $1.77 \mathrm{~cm}^{2}$ disks. The material mass loading of the electrodes was ca. $4-6 \mathrm{mg} \mathrm{cm}^{-2}$. Standard two-electrode CR2032 coin-type cells were assembled in an argon-filled glove box with Celgard 2325 (MTI, Richmond, CA, USA) membrane as separator and Li foil as counter electrode. $\mathrm{LiPF}_{6}(1 \mathrm{M})$ in EC/DMC (1:1 by wt.) battery electrolyte (Aldrich) and TCE918 electrolyte $\left(\mathrm{LiPF}_{6}\right.$ solution in a mix of organic carbonates, Guangzhou Tinci Materials Technology Co. Ltd., Guangzhou, China) were used.

Table 1. Compositions of electrodes.

\begin{tabular}{|c|c|c|c|c|c|}
\hline Electrodes & $\begin{array}{c}\text { Active Material, } \\
\text { wt. } \%\end{array}$ & $\begin{array}{c}\text { C, wt. } \\
\%\end{array}$ & $\begin{array}{l}\text { PEDOT:PSS, } \\
\text { wt. } \%\end{array}$ & $\begin{array}{c}\text { CMC, wt. } \\
\%\end{array}$ & $\begin{array}{l}\text { PVDF, wt. } \\
\%\end{array}$ \\
\hline LFP PEDOT:PSS/CMC $_{\text {PST }}$ & 92 & 4 & 2 & 2 & - \\
\hline $\mathrm{LFP}_{\mathrm{CMC}}$ & 92 & 4 & - & 4 & - \\
\hline LFP $_{\text {PVDF }}$ & 84 & 8 & - & - & 8 \\
\hline LFMP $_{\text {PEDOT:PSS/CMC }}$ & 92 & 4 & 2 & 2 & - \\
\hline LFMP $_{\text {PVDF }}$ & 80 & 10 & - & - & 10 \\
\hline LMOPEDOT:PSS/CMC & 86 & 10 & 2 & 2 & - \\
\hline $\mathrm{LMO}_{\mathrm{CMC}}$ & 92 & 4 & - & 4 & - \\
\hline $\mathrm{LMO}_{\mathrm{PVDF}}$ & 80 & 10 & - & - & 10 \\
\hline LTOPEDOT:PSS/CMC & 90 & 6 & 2 & 2 & - \\
\hline $\mathrm{LTO}_{\mathrm{CMC}}$ & 90 & 6 & - & 4 & - \\
\hline $\mathrm{LTO}_{\mathrm{PVDF}}$ & 80 & 10 & - & - & 10 \\
\hline
\end{tabular}

Galvanostatic charge-discharge (GCD) tests were performed on an automatic GCD battery cell test instrument CT-3008W-5V10mA (Neware Co., Shenzhen, China) in the current density range from 0.2 to $30 \mathrm{C}$ at room temperature $\left(20 \pm 2{ }^{\circ} \mathrm{C}\right)$. All experimental capacity values in figures were normalized to 
the total mass of electrode excluding current collector, if not stated otherwise. Cyclic voltammetry was performed on Autolab PGSTAT 30 potentiostat/galvanostat (Eco-Chemie, Utrecht, The Netherlands).

The morphology of prepared composites was characterized by scanning electron microscopy (SEM, SUPRA 40VP Carl Zeiss, Oberkochen, Germany).

\section{Results}

\subsection{Morphology of Electrodes}

It has been reported that the adhesion of the electrodes with CMC binder is much stronger than that of the electrodes with PVDF binder. This was explained by strong hydrogen bonding of the carboxyl and hydroxyl groups in CMC with the active material and the current collector [71].

This effect is also true for all active materials studied with PEDOT:PSS/CMC binder. Compared to PVDF, introduction of PEDOT:PSS/CMC binder resulted in improvement of electrode morphology, electrode layer integrity, and better adhesion of electrode layer to current collector. Figures 1-4 demonstrate different aspects of electrode morphology on the example of different active materials.

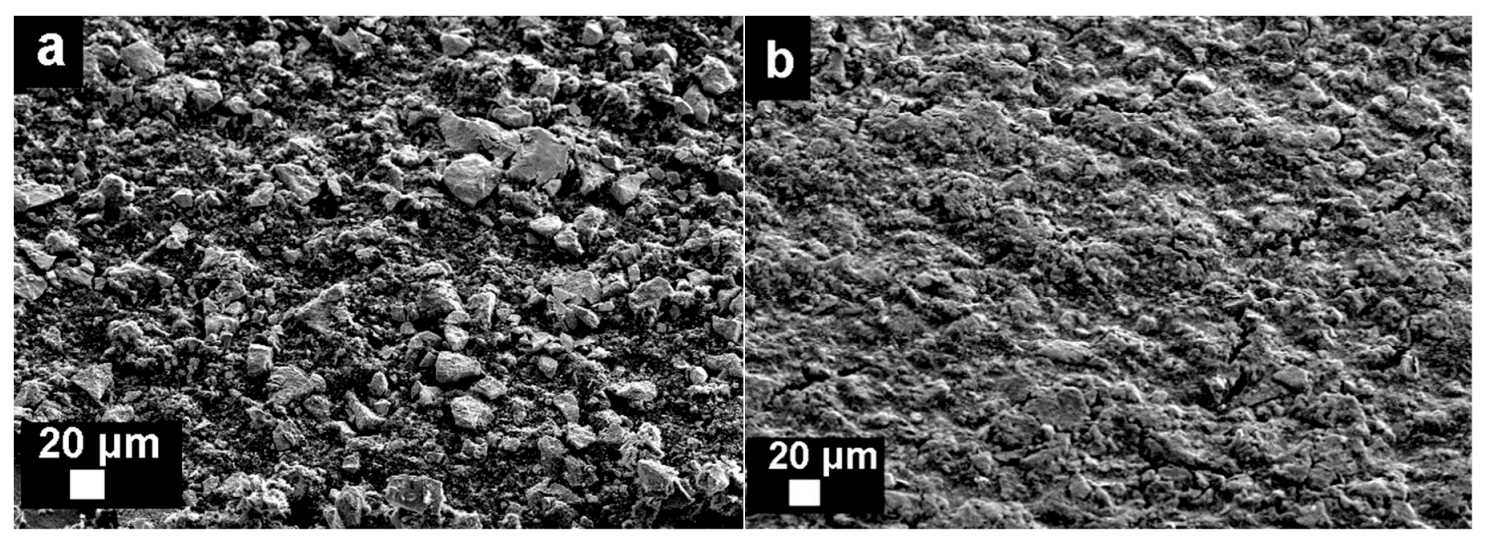

Figure 1. SEM images of freshly prepared electrodes: (a) LMOPVDF; and (b) LMOPEDOT:PSS/CMC (our data from Ref. [66]).

To show the difference in the morphological properties of electrode materials with PVDF and PEDOT:PSS/CMC binders, typical scanning electron microscopy (SEM) images of LMO-electrodes with the same amount of carbon black are presented in Figure 1. The electrode layer with PEDOT:PSS/CMC binder demonstrates denser and smoother surface than the electrode with PVDF binder. The polymer coating is visible on the surface of LMO grains and efficiently fills the gaps between them and carbon black.

Sectional SEM images confirm good density and integrity of the electrode layers with PEDOT:PSS/CMC binder. For instance, Figure 2a,b shows the electrode layers of LTOPEDOT:PSS/CMC and LFMP PEDOT:PSS/CMC, which perfectly adhere to the current collector. The electrode layers with PEDOT:PSS/CMC binder successfully maintained integrity after long galvanostatic charge-discharge (GCD) tests $[64,66,68,69]$.

As the conductive PEDOT:PSS/CMC binder besides binding function should improve the electrical contact between the particles in the composite material, its distribution should be uniform to maintain conductivity. The distribution of the main elements mapped using locally-resolved EDX analysis is shown in Figure 2c on the example of LTOPEDOT:PSS/CMC. Relatively uniform distribution of Ti and C over the electrode suggests that the solid particles in the electrode slurry were thoroughly mixed, while S mapping confirms uniform distribution of the sulfur-containing PEDOT:PSS component of the binder.

Figure 3 shows typical SEM images of LFP PEDOT:PSS/CMC electrode that demonstrate the smooth surface of LFP grains wrapped with conducting polymer binder. We can see the high completeness of LFP grain wrapping that remains intact after charge-discharge cycling of the material in coin cell (Figure $3 b$ ). It can be supposed that the wrapping of active grains with conducting polymer 
maintains good electric contacts in the electrode material, and could be one of the factors providing high electrochemical performance of the electrode material.
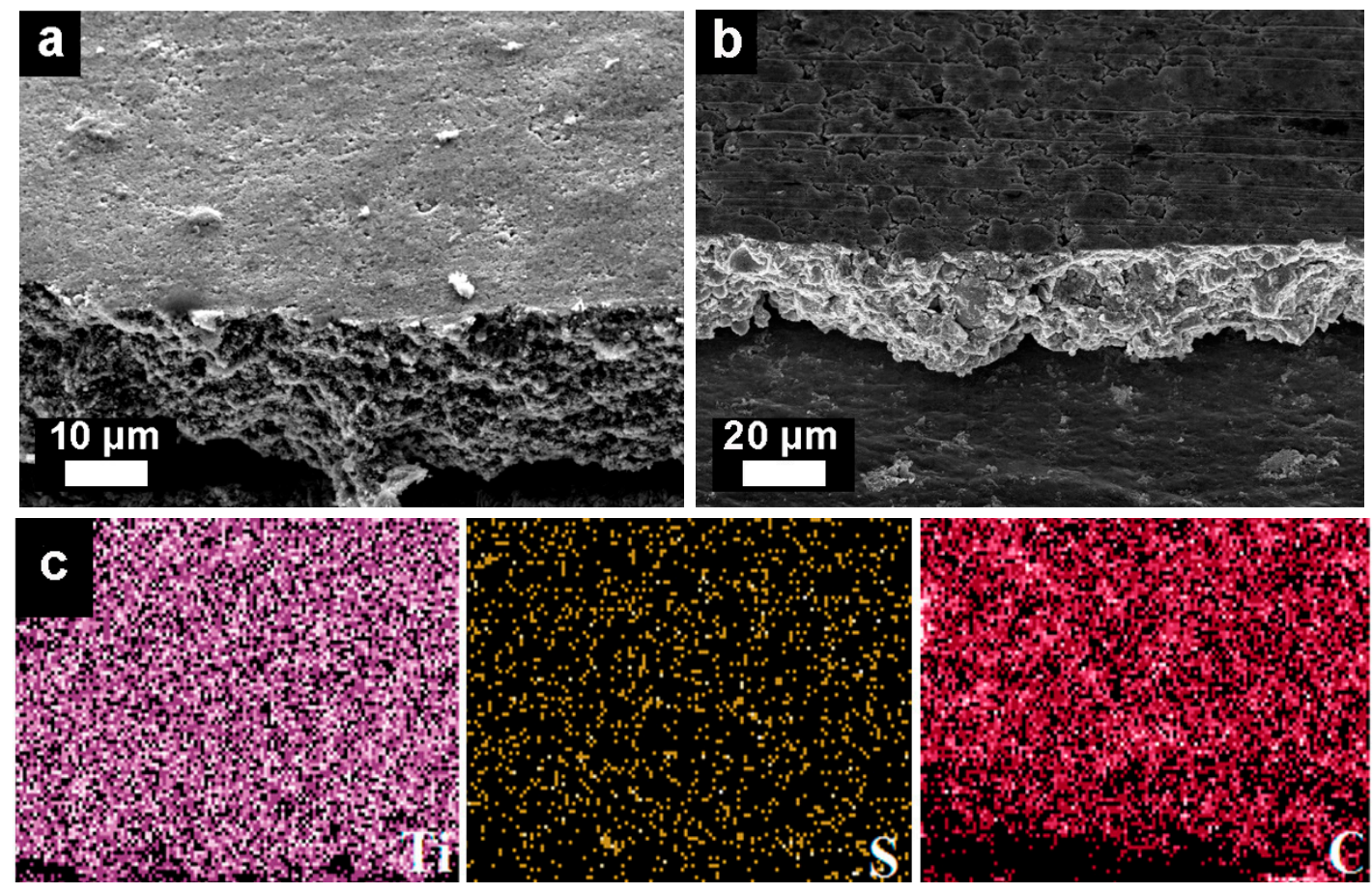

Figure 2. Sectional SEM images of freshly prepared electrode layers on Al current collector: (a) LTOPEDOT:PSS/CMC; (b) LFMP PEDOT:PSS/CMC; and (c) EDX element mapping of LTOPEDOT:PSS/CMC electrode (our data from Ref. $[64,65]$ ).

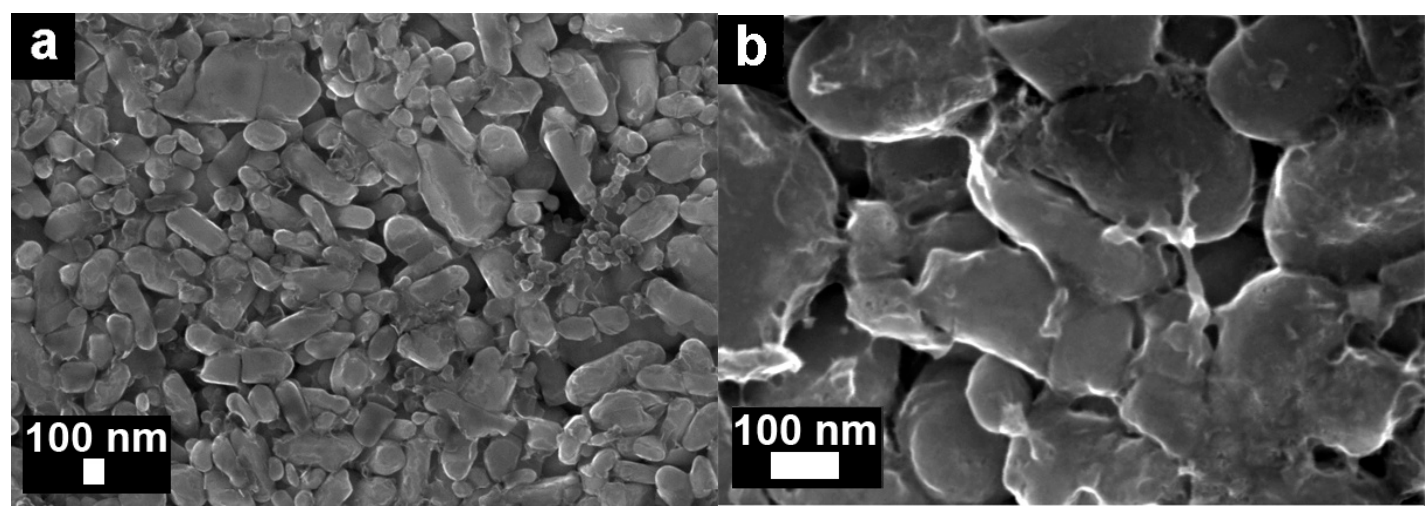

Figure 3. SEM images of LFP PEDOT:PSS/CMC electrodes: (a) freshly prepared; and (b) after long-term cycling (our data from Ref. [69]).

Figure 4 shows photographs of the surfaces of LMOPVDF and LMOPEDOT:PSS/CMC electrodes after 200 charge-discharge cycles. As shown in Figure 4, the active layer of PVDF-bound electrode had cracked and partially delaminated from Al current collector, while PEDOT:PSS/CMC-bound electrode maintains electrode layer integrity. Our observations are in consistence with the results of comparative studies of LMO electrodes with different binders in [72], where LMO electrodes with CMC binder had more compact active layer with higher adhesion to substrate after long-term cycling than the electrodes with PVDF binder. Compared with conventional PVDF-based electrodes, the $\mathrm{CMC} / \mathrm{LiNi}_{0.4} \mathrm{Co}_{0.2} \mathrm{Mn}_{0.4} \mathrm{O}_{2}$ cathodes also displayed more uniform distribution of active grains and carbon particles together with strong adhesion among the particles and with the current collector, preventing the delamination of the electrode layer [62]. 


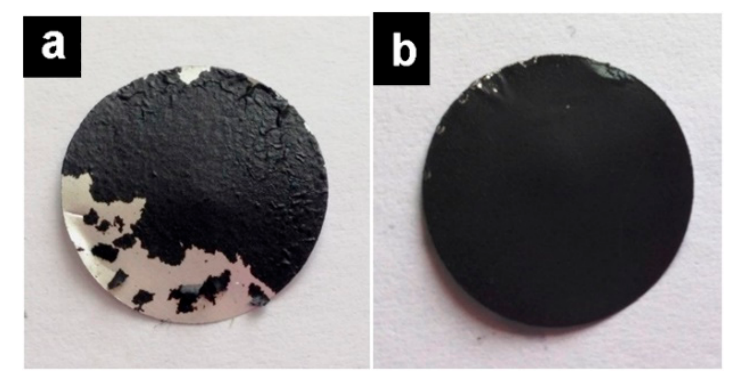

Figure 4. Photographs of LMO electrodes after 200 charge-discharge cycles: (a) LMOPVDF; and (b) LMOPEDOT:PSS/CMC (our data from Ref. [66]).

\subsection{Cyclic Voltammetry}

Cyclic voltammograms of electrodes with different active materials (LFP, LFMP, LMO, and LTO) and two types of binder (PEDOT:PSS/CMC and PVDF) are shown in Figure 5. For proper comparison, the currents in cyclic voltammograms are normalized by the mass of active material. As shown in Figure 5, in most cases, the voltammetric responses of electrodes with conductive binder are more reversible and PEDOT:PSS/CMC-bound electrodes show higher capacities than PVDF-bound ones. This is especially evident from CVs of LTO and LFP electrodes, where the significant differences in the shapes of voltammetric responses indirectly indicate different conditions of charge transfer during the charge-discharge cycles. Both LTO and LFP electrodes with combined conductive binder demonstrated higher peak currents and lower peak-to-peak separation compared to PVDF-bound materials at the same scan rate. The obtained data indicate increased reversibility of lithium intercalation processes in LTO and LFP electrodes and lowering of internal resistance, when a conductive polymer additive is introduced. The peak currents $\left(I_{p}\right)$ were almost linear with square root of the scan rates, demonstrating that the electrochemical kinetics was diffusion-controlled with slow intercalation of lithium ions.
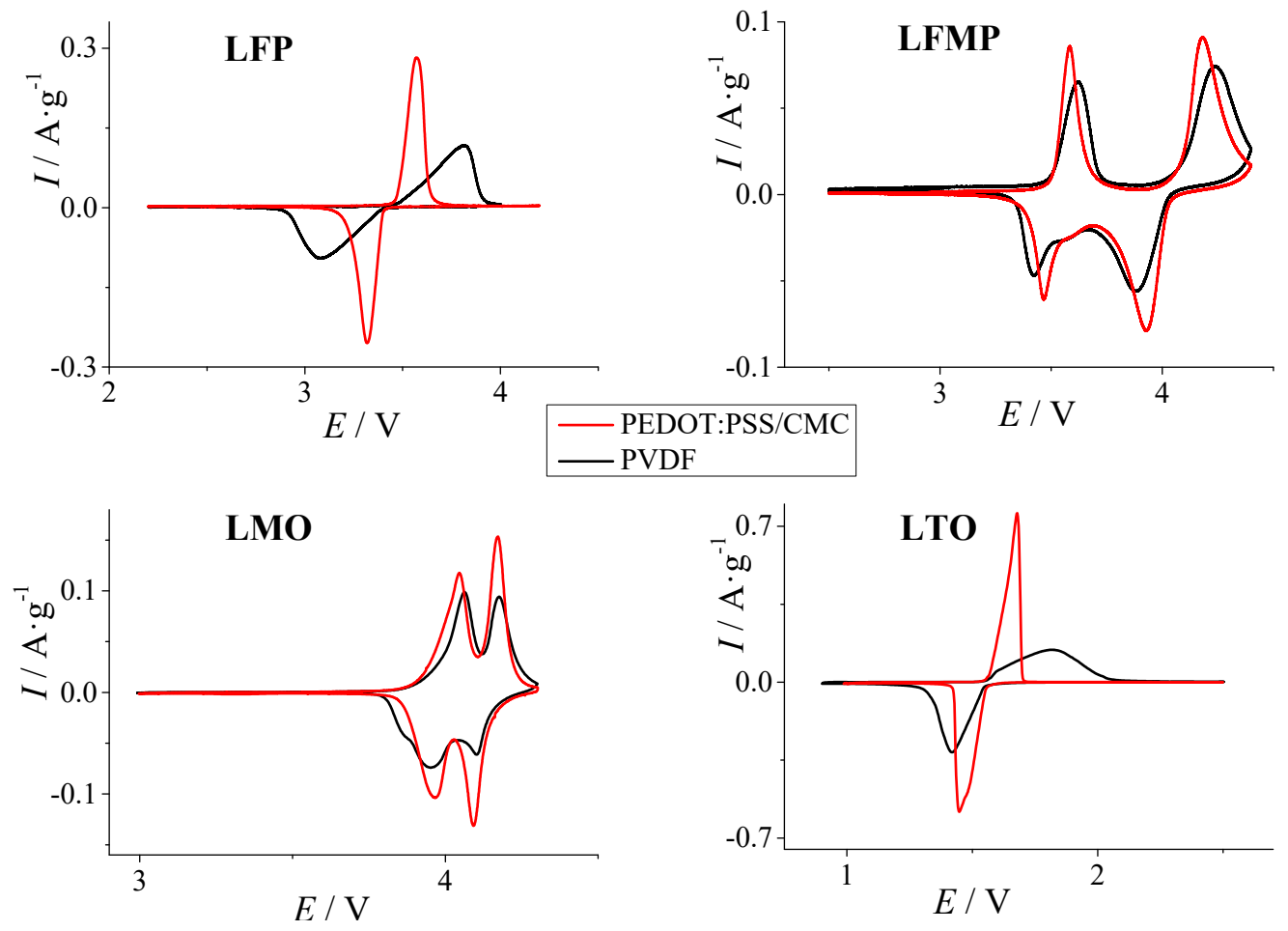

Figure 5. Cyclic voltammograms of freshly prepared LFP, LFMP, LMO, and LTO electrodes with PVDF and PEDOT:PSS/CMC binders at $v=0.1 \mathrm{mV} \cdot \mathrm{s}^{-1}$ (3rd cycles presented) (based on our data in Ref. [64-67]). 
The difference in the shape of cyclic voltammograms for $\mathrm{LiFe}_{0.4} \mathrm{Mn}_{0.6} \mathrm{PO}_{4}$ and $\mathrm{LiMn}_{2} \mathrm{O}_{4}$ was less expressed, probably due to higher intrinsic conductivity of these compounds, whereas the normalized currents were also higher in the case of conductive polymer binder. It indicates on the enhanced specific capacities of electrodes with conductive binder in comparison with PVDF-bound materials.

\subsection{Galvanostatic Charge-Discharge}

The comparison of GCD tests of cells with electrodes with different active materials LFP, LFMP, LMO, and LTO and three types of binder PEDOT:PSS/CMC, CMC, and PVDF, (except for LFMP, where data with only two binders are available) at $0.2 \mathrm{C}$ current is presented in Figure 6 , and the values of specific capacities of the electrodes both normalized by the total mass of electrodes excluding current collector ( $\left.Q_{\text {electrode }}\right)$ and by mass of electroactive material $\left(Q_{\text {electroactive material }}\right)$ are given in Table 2. The electrochemical performance tests were carried out on an automatic galvanostatic charge-discharge battery cell test instrument for the series of 3-4 batteries of given composition. The results on the specific capacities were well reproducible.
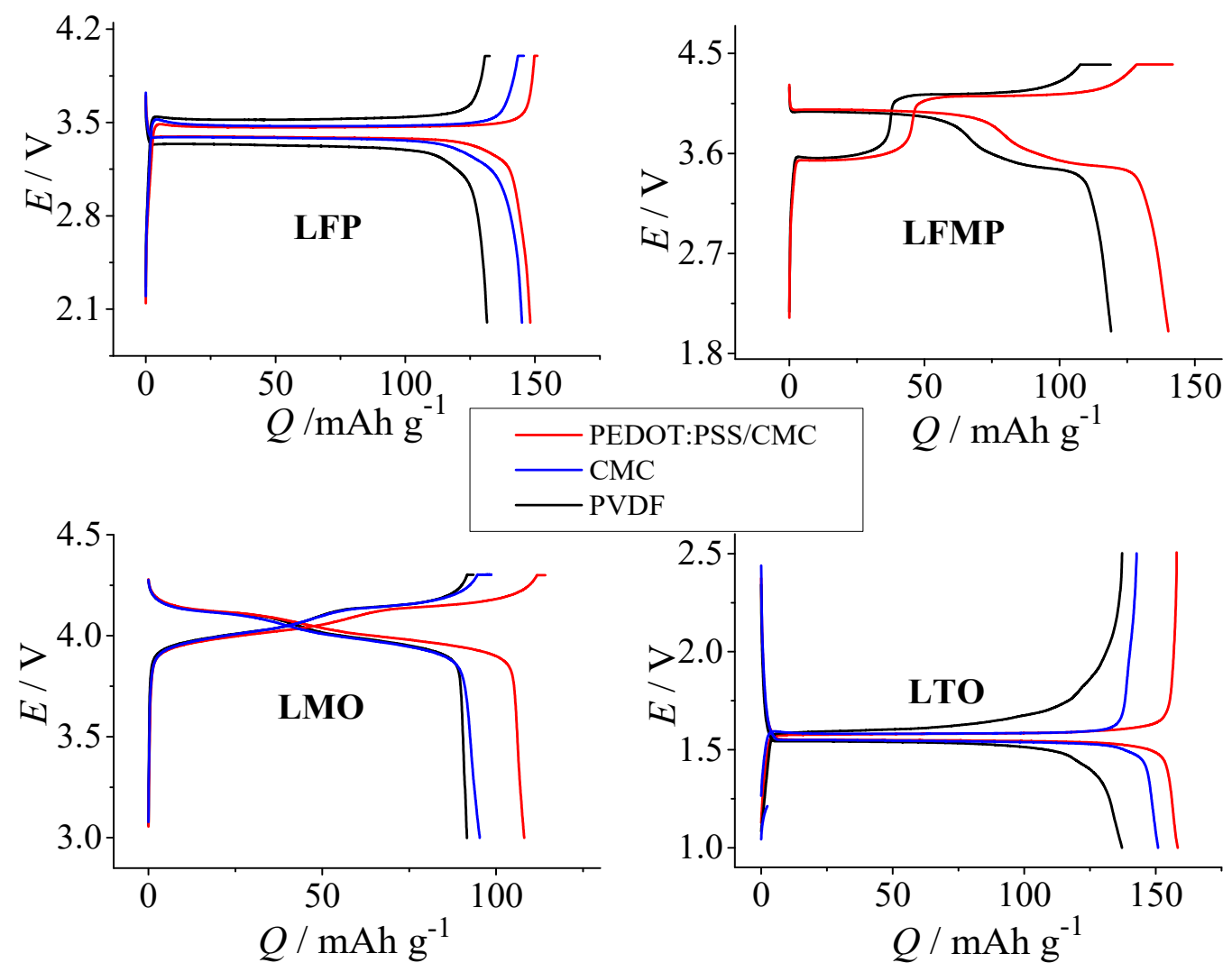

Figure 6. GCD curves of LFP, LFMP, LMO, LTO electrodes with PEDOT:PSS/CMC, CMC, and PVDF binders at 0.2 C (based on our data in Ref. [64-67]).

It can be seen that the highest values of capacities at $0.2 \mathrm{C}$ normalized by electrode mass ( $Q_{\text {electrode }}$ ) were obtained for PEDOT:PSS/CMC-bound electrodes. These values are higher than those for PVDF-bound electrodes by $14 \%, 14 \%, 15 \%$, and $13 \%$ for LFP, LFMP, LMO, and LTO, respectively. In the case of CMC-bound electrodes, we mainly see intermediate values of specific capacities ( $\left.Q_{\text {electrode }}\right)$. However, after normalization by mass of electroactive material $\left(Q_{\text {electroactive material }}\right)$, the lowest values were obtained for $\mathrm{LMO}_{\mathrm{CMC}}$ material, whereas for $\mathrm{LTO}_{\mathrm{CMC}}$ we can see comparable values with those of PEDOT:PSS/CMC-bound electrodes at low current densities (0.2C). Thus, in all cases, the employment of PEDOT:PSS/CMC conductive polymer binder ( $4 \mathrm{wt}$. \% total) along with small amount of carbon black improved the specific capacity of electrodes, both $Q_{\text {electrode }}$ and $Q_{\text {electroactive material }}$. 
Table 2. Specific capacities of electrodes with three binders (PEDOT:PSS/CMC, CMC, and PVDF) at $0.2 \mathrm{C}$.

\begin{tabular}{|c|c|c|}
\hline Electrode & $Q_{\text {electrode, }} \mathrm{mAhg}^{-1}$ & $Q_{\text {electroactive material }}, \mathrm{mAhg}^{-1}$ \\
\hline LFP PEDOT:PSS/CMC & 149 & 162 \\
\hline $\mathrm{LFP}_{\mathrm{CMC}}$ & 145 & 158 \\
\hline $\mathrm{LFP}_{\mathrm{PVDF}}$ & 131 & 156 \\
\hline LFMP $_{\text {PEDOT:PSS/CMC }}$ & 139 & 151 \\
\hline LFMP $_{\text {PVDF }}$ & 119 & 142 \\
\hline LMOPEDOT:PSS/CMC & 108 & 126 \\
\hline $\mathrm{LMO}_{\mathrm{CMC}}$ & 95 & 103 \\
\hline $\mathrm{LMO}_{\mathrm{PVDF}}$ & 92 & 115 \\
\hline LTOPEDOT:PSS/CMC & 158 & 174 \\
\hline $\mathrm{LTO}_{\mathrm{CMC}}$ & 151 & 168 \\
\hline LTOPVDF $_{\text {PTD }}$ & 137 & 171 \\
\hline
\end{tabular}

Normalization of the capacities by the mass of the electrode excluding current collector is important for assessing the practical capacity. The increase of specific capacity ( $\left(Q_{\text {electrode }}\right)$ at low discharge currents $(0.2 \mathrm{C})$ is primarily due to higher mass fraction of the active material in PEDOT:PSS/CMC-bound electrodes (extra 6-10 wt. \%, see Table 1) and to improved ionic and electronic conductivity of material, facilitating its full utilization.

The advantages of proposed PEDOT:PSS/CMC binder are most noticeable at the high charge-discharge rates. The C-rate performance of electrode materials with different binders is compared in Figure 7. The most effective impact of conductive binder PEDOT:PSS/CMC was observed for LFP (at 5 C) and LTO (at 20 and 30 C) materials, whereas active materials containing manganese show less significant increase of the specific capacity that may be due to higher intrinsic conductivity of these materials (both electronic and ionic). In the case of CMC-bound electrodes, the values of specific capacities at low current densities were lower or comparable with those of PEDOT:PSS/CMC bound electrodes, whereas high C-rate capability of PEDOT:PSS/CMC bound electrodes was superior, especially for LMO.

At high currents, the capacities of PVDF-bound electrodes were lower than the capacities of PEDOT:PSS/CMC-bound electrodes. Such a difference in the behavior of electrodes with PEDOT:PSS/CMC and PVDF binders at high discharge rates may be due to lower kinetic and diffusion limitations when using the PEDOT:PSS/CMC binder. Thus, with an increase in the current (or discharge rate), the capacities of electrodes modified with a combined conductive binder are higher than for electrodes of conventional composition, which indicates a more efficient and complete recharging process at high currents.

It should be noted that the conductivity of PEDOT:PSS component is not sufficient to produce carbon black-free electrode materials without the loss of power characteristics, as shown in several our works [64,67]. It is also shown in [64] that extremely high carbon black content (20 wt. \%) does not improve the specific capacity of LTO electrodes at high discharge rates, as one would expect.

These results suggest the crucial importance of balance of different components of electrode materials. Special attention should be paid to ionic and electronic conductivity of the intergranular medium (polymer binder, carbon black) wherein the electrolyte is located and good wettability of the active grains by electrolyte. 

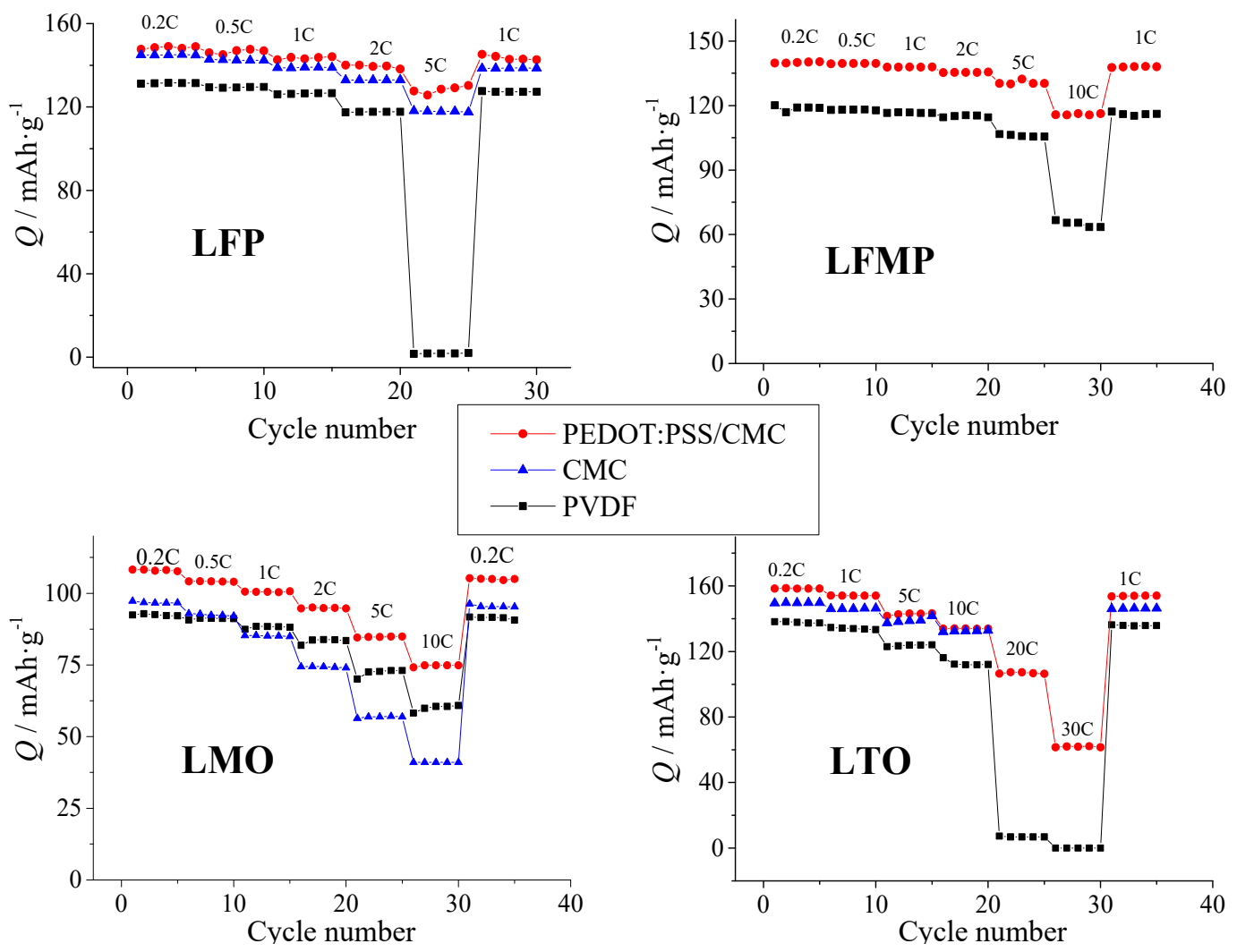

Figure 7. C-rate capabilities of electrodes with PEDOT:PSS/CMC, CMC, and PVDF binders (based on our data in Ref. [64-67]).

\subsection{Cycling Performance}

Cycle life stability of tested batteries with different electrode materials is shown in Figure 8. The cycling stability tests showed satisfactory capacity retention for materials with PEDOT:PSS/CMC binder-it is superior to that of the PVDF-bound electrodes or at least on the same level. The most effective impact of PEDOT:PSS/CMC binder on the cycling stability was observed in the case of LTO material. Based on the results of [71] and our data [56], we assume that PEDOT:PSS and CMC polymers suppress the changes in the surface structure of the LTO material, since polymers wrap the LTO grains and form a protective layer that effectively inhibits side reactions and protects the active material from interaction with the electrolyte, without slowing down lithium transport.

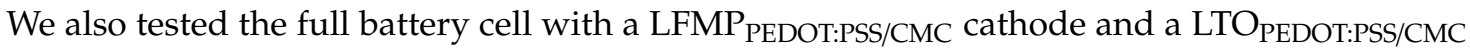
anode. The mass loading ratio of LFMP ${ }_{\text {PEDOT:PSS/CMC }}$ and LTO $_{\text {PEDOT:PSS/CMC }}$ electrodes was 0.879 . The discharge capacity of the battery cell is presented in Figure 9 normalized to the mass of

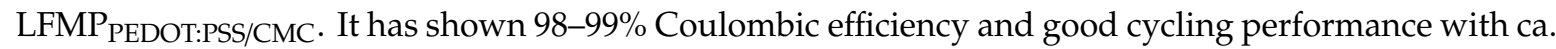
$16 \%$ capacity decay over 1000 charge-discharge cycles, these values matching commercial standards. 

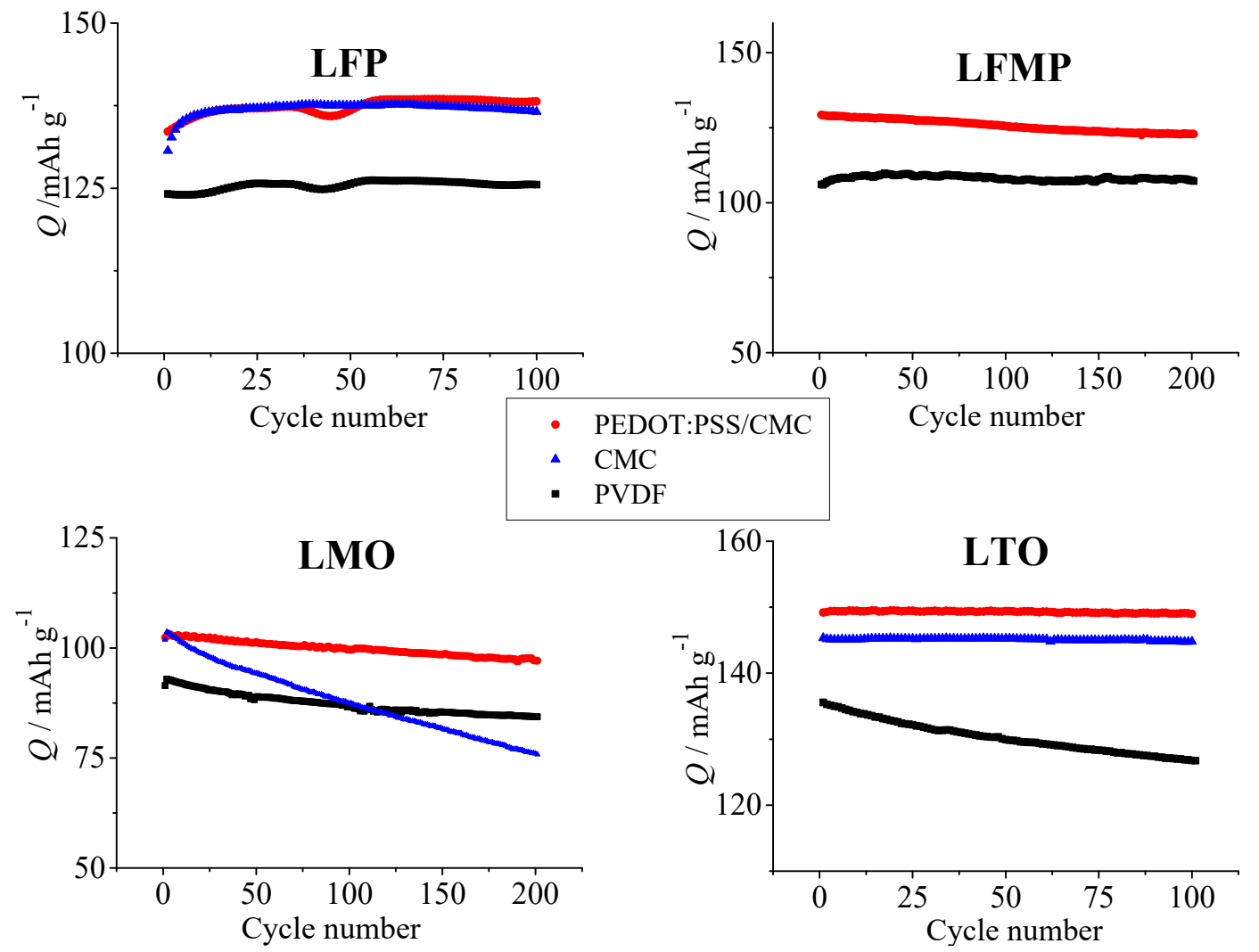

Figure 8. Cycling performance at $1 \mathrm{C}$ charge and discharge for electrodes with PEDOT:PSS/CMC, CMC, and PVDF binders (based on our data in Ref. [64-67]).

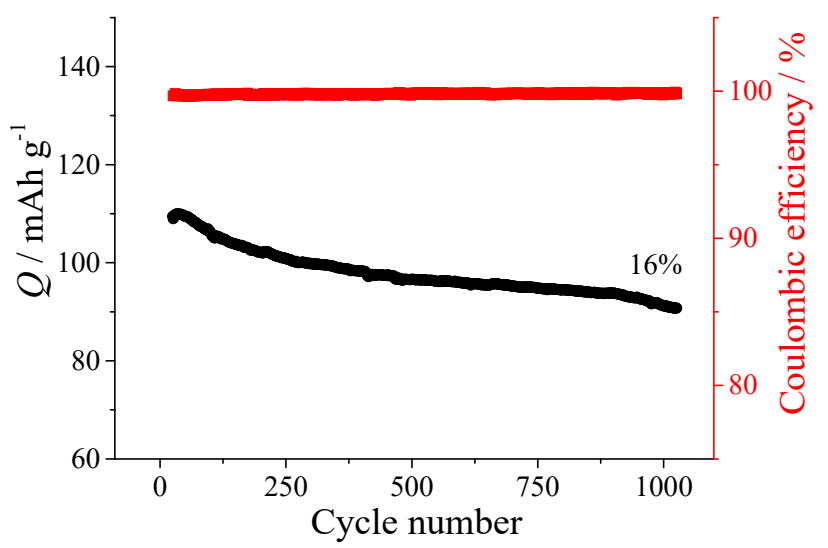

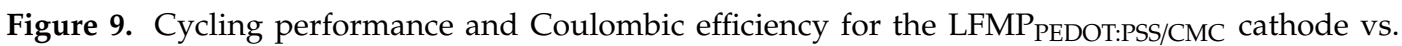
LTOPEDOT:PSS/CMC anode at $1 \mathrm{C}$ (based on our data in Ref. [64]).

\section{Discussion}

In this section, we present a short summary and discussion of specific capacity values for different electrode materials with CMC and PVDF taken from the literature (see Table 3) compared to the data for materials with PEDOT:PSS/CMC binder. 
Table 3. Specific capacities of different electrode materials. $Q_{\text {electroactive material, capacities normalized }}$ by electroactive mass $\left(\mathrm{mAh} \cdot \mathrm{g}^{-1}\right)$. (In the case of estimates from graphical dependencies, given values may be approximate.)

\begin{tabular}{|c|c|c|c|c|}
\hline \multirow{2}{*}{ Cathode Material Based on $\mathrm{LiFePO}_{4}$} & \multicolumn{3}{|c|}{$Q_{\text {LFP }}, \mathrm{mAh} \cdot \mathrm{g}^{-1}$} & \multirow{2}{*}{ Ref } \\
\hline & $0.2 \mathrm{C}$ & $1 \mathrm{C}$ & $10 \mathrm{C}$ & \\
\hline [LiFePO 4 /graphene aerogel-10\%]/C/PVDF & 168 & 155 & 115 & [73] \\
\hline$\left[\mathrm{LiFePO}_{4} /\right.$ activated carbon/graphene]/C/PVDF & - & 167 & 143 & [10] \\
\hline$\left[\mathrm{LiFePO}_{4} /\right.$ graphene]/C/PVDF & - & 163 & 137 & [10] \\
\hline [Carbon-coated LFP microspheres]/C/PVDF & 143 & 113 & - & [11] \\
\hline $\mathrm{C}-\mathrm{LiFePO}_{4} / \mathrm{PVDF} / \mathrm{C}$ on $\mathrm{Al}$ substrate & - & 143 & 92 & [74] \\
\hline $\mathrm{PEDOT} / \mathrm{LiFePO}_{4} / \mathrm{PVDF}$ on $\mathrm{C}$-coated $\mathrm{Al}$ substrate & 160 & 155 & 125 & [75] \\
\hline $\mathrm{C}-\mathrm{LiFePO}_{4} / \mathrm{PANI} / \mathrm{C} / \mathrm{PVDF}$ & 160 & 150 & 80 & [30] \\
\hline$\left[\mathrm{LiFePO}_{4}-\mathrm{PEDOT}\right.$ blend]/C/PVDF & 135 & 125 & - & [36] \\
\hline $\mathrm{LiFePO}_{4} / \mathrm{PANI} / \mathrm{C} / \mathrm{PTFE}$ & 150 & 120 & 65 & [25] \\
\hline $\mathrm{LiFePO}_{4} / \mathrm{PPy} / \mathrm{C} / \mathrm{PTFE}$ & 150 & 130 & 100 & [25] \\
\hline $\mathrm{LiFePO}_{4}$-PEDOT/PVDF & 163 & 151 & 123 & [75] \\
\hline $\mathrm{LiFePO}_{4} / \mathrm{PEDOT}$ (binder free) & 125 & 105 & - & [35] \\
\hline $\mathrm{C}-\mathrm{LiFePO} / \mathrm{C} / \mathrm{PVDF}$ on PEDOT-coated Al substrate & - & 151 & 110 & [74] \\
\hline $\mathrm{LiFePO}_{4} / \mathrm{C} /$ xanthan gum & 157 & 138 & $80(5 \mathrm{C})$ & [76] \\
\hline $\mathrm{LiFePO}_{4} / \mathrm{C} /$ cyanoethylated carboxymethyl chitosan & 158 & 139 & $90(5 \mathrm{C})$ & [52] \\
\hline $\mathrm{LiFePO}_{4} / \mathrm{C} / \mathrm{CMC}$ & 155 & 128 & $78(5 \mathrm{C})$ & [52] \\
\hline $\mathrm{LiFePO}_{4} / \mathrm{C} / \mathrm{CMC}$ & 130 & 115 & 70 & [77] \\
\hline $\mathrm{LiFePO}_{4} / \mathrm{C} / \mathrm{CMC}$ & - & 140 & - & [78] \\
\hline $\mathrm{LiFePO}_{4} / \mathrm{C} / \mathrm{CMC}$ & 176 & 140 & $90(5 \mathrm{C})$ & [61] \\
\hline $\mathrm{LiFePO}_{4} / \mathrm{C} / \mathrm{CMC}$ & 150 & 137 & $80(5 \mathrm{C})$ & [79] \\
\hline $\mathrm{LiFePO}_{4} / \mathrm{C} / \mathrm{CMC}$ & - & 115 & $75(8 \mathrm{C})$ & [77] \\
\hline $\mathrm{LiFePO}_{4} / \mathrm{C} /[$ humic acid-CMC] & - & 147 & $105(8 \mathrm{C})$ & [77] \\
\hline $\mathrm{LiFePO}_{4} / \mathrm{C} / \mathrm{PEDOT}$ :PSS & 155 & 135 & 90 & [80] \\
\hline C-LFP/PEDOT:PSS (8\%) & - & 110 & - & [55] \\
\hline C-LiFePO 4 /C/PEDOT:PSS/CMC & 161 & 155 & $139(5 \mathrm{C})$ & [67] \\
\hline \multirow{2}{*}{ Cathode Material Based on $\mathrm{LiFeMnPO}_{4}$} & \multicolumn{3}{|c|}{$Q_{\text {LFMP }}, \mathrm{mAh} \mathrm{g}^{-1}$} & \multirow{2}{*}{ Ref } \\
\hline & $0.2 \mathrm{C}$ & $1 \mathrm{C}$ & $10 \mathrm{C}$ & \\
\hline $\mathrm{LiFe}_{0.2} \mathrm{Mn}_{0.8} \mathrm{PO}_{4} / \mathrm{C} / \mathrm{PVDF}$ & 112 & 98 & $55(5 \mathrm{C})$ & [81] \\
\hline $\mathrm{LiMn}_{0.9} \mathrm{Fe}_{0.1} \mathrm{PO} 4 / \mathrm{C} / \mathrm{PVDF}$ & 135 & 75 & - & [82] \\
\hline $\mathrm{LiFe}_{0.4} \mathrm{Mn}_{0.6} \mathrm{PO}_{4} / \mathrm{C} / \mathrm{PVDF}$ & 146 & 140 & - & [82] \\
\hline$\left[\mathrm{LiMn}_{0.5} \mathrm{Fe}_{0.5} \mathrm{PO}_{4} / \mathrm{C}\right] / \mathrm{C} / \mathrm{PVDF}$ & 142 & 130 & 105 & [83] \\
\hline $\begin{array}{c}{\left[\mathrm{LiFe}_{0.6} \mathrm{Mn}_{0.4} \mathrm{PO}_{4} / \mathrm{C} \text { composites with }\right.} \\
\text { MWCNTs }] / \mathrm{C} / \mathrm{PVDF}\end{array}$ & - & 145 & 125 & [19] \\
\hline $\begin{array}{l}\text { Carbon-coated nanoclustered } \\
\mathrm{LiMn}_{0.71} \mathrm{Fe}_{0.29} \mathrm{PO}_{4} / \mathrm{C} / \mathrm{PVDF}\end{array}$ & 156 & 142 & $85(7 \mathrm{C})$ & [18] \\
\hline$\left[\mathrm{LiFe}_{0.8} \mathrm{Mn}_{0.2} \mathrm{PO}_{4} / \mathrm{C}\right] / \mathrm{C} / \mathrm{PTFE}$ & 152 & 147 & 122 & [84] \\
\hline$\left[\mathrm{LiFe}_{0.9} \mathrm{Mn}_{0.1} \mathrm{PO}_{4} / \mathrm{C}\right] / \mathrm{C} / \mathrm{PTFE}$ & - & 140 & 110 & [85] \\
\hline $\mathrm{C}-\mathrm{LiMn}_{0.8} \mathrm{Fe}_{0.2} \mathrm{PO}_{4} / \mathrm{C} / \mathrm{PVDF}$ & 157 & 150 & $94-95$ & [86] \\
\hline$\left[\mathrm{LiMn}_{0.8} \mathrm{Fe}_{0.2} \mathrm{PO}_{4} / \mathrm{C}\right.$ nanorods $] / \mathrm{C} / \mathrm{PVDF}$ & 145 & 130 & - & [87] \\
\hline $\begin{array}{c}{\left[\mathrm{LiMn}_{0.5} \mathrm{Fe}_{0.5} \mathrm{PO}_{4} / \mathrm{C} \text { nanorods, } \mathrm{LiAlO}_{2}\right.} \\
\text { modification }] / \mathrm{C} / \mathrm{PVDF}\end{array}$ & 132 & 120 & $105(5 \mathrm{C})$ & {$[14]$} \\
\hline$\left[\mathrm{LiFe}_{0.5} \mathrm{Mn}_{0.5} \mathrm{PO}_{4} / \mathrm{C}\right.$ nanorods $] / \mathrm{C} / \mathrm{PVDF}$ & 157 & 143 & 102 & [9] \\
\hline $\begin{array}{c}\text { [Graphene wrapped } \mathrm{LiMn}_{0.5} \mathrm{Fe}_{0.5} \mathrm{PO}_{4} \\
\text { composite]/C/PVDF }\end{array}$ & 156 & 126 & 101 & [88] \\
\hline$\left[\mathrm{LiFe}_{0.5} \mathrm{Mn}_{0.5} \mathrm{PO}_{4} / \mathrm{C}\right.$ nanoplates]/C/PVDF & - & 120 & $60(9 \mathrm{C})$ & [89] \\
\hline$\left[\mathrm{LiFe}_{0.5} \mathrm{Mn}_{0.5} \mathrm{PO}_{4} / \mathrm{C}\right] / \mathrm{C} / \mathrm{PVDF}$ & - & 141 & $121(5 \mathrm{C})$ & [90] \\
\hline $\mathrm{LiMn}_{0.8} \mathrm{Fe}_{0.2} \mathrm{PO}_{4} / \mathrm{C} / \mathrm{LA} 133$ & 155 & 145 & 130 & [91] \\
\hline $\mathrm{LiFe}_{0.4} \mathrm{Mn}_{0.6} \mathrm{PO}_{4} / \mathrm{C} / \mathrm{PEDOT}: \mathrm{PSS} / \mathrm{CMC}$ & 151 & 131 & 129 & [65] \\
\hline
\end{tabular}


Table 3. Cont.

\begin{tabular}{|c|c|c|c|c|}
\hline \multirow{2}{*}{ Cathode Material Based on $\mathrm{LiFePO}_{4}$} & \multicolumn{3}{|c|}{$Q_{\mathrm{LFP}}, \mathrm{mAh} \cdot \mathrm{g}^{-1}$} & \multirow{2}{*}{ Ref } \\
\hline & $0.2 \mathrm{C}$ & $1 \mathrm{C}$ & $10 \mathrm{C}$ & \\
\hline \multirow{2}{*}{ Cathode Material Based on $\mathrm{LiMn}_{2} \mathrm{O}_{4}$} & \multicolumn{3}{|c|}{$Q_{\text {LMO }}, \mathrm{mAh} \mathrm{g}^{-1}$} & \multirow{2}{*}{ Ref } \\
\hline & $0.2 \mathrm{C}$ & $1 \mathrm{C}$ & $10 \mathrm{C}$ & \\
\hline Multilayered porous ultralong $\mathrm{LiMn}_{2} \mathrm{O}_{4}$ nanorods/C/PVDF & 134 & 119 & 102 & [13] \\
\hline Sandwiched $\mathrm{LiMn}_{2} \mathrm{O}_{4} @ \mathrm{rGO}$ nanocomposites/C/PVDF & 124 & 116 & 97 & [12] \\
\hline$\left[\mathrm{LiMn}_{2} \mathrm{O}_{4}\right.$ with $\mathrm{LiNbO}_{3}$ coating]/C/PVDF & - & 122 & 117 & [92] \\
\hline$\left[\mathrm{LiMn}_{2} \mathrm{O}_{4}\right.$ surface modified by a $\mathrm{Mn}^{4+}$-rich phase]/C/PVDF & - & 123 & $107(7 \mathrm{C})$ & [93] \\
\hline Al-doped $\mathrm{LiMn}_{2} \mathrm{O}_{4} / \mathrm{C} / \mathrm{PVDF} /$ & 116 & 110 & 102 & [94] \\
\hline Sc-doped $\mathrm{LiMn}_{2} \mathrm{O}_{4} / \mathrm{C} / \mathrm{PVDF}$ & - & 111 & 96 & [95] \\
\hline $\mathrm{LiMn}_{2} \mathrm{O}_{4}$ coated by polypyrrole/C/PVDF & - & 117 & 92 & [27] \\
\hline$\left[\mathrm{Li}_{1.01} \mathrm{Mn}_{1.97} \mathrm{O}_{4}\right.$ surface modified by PEDOT]/PVDF & 119 & 111 & - & [33] \\
\hline $\mathrm{LiMn}_{2} \mathrm{O}_{4} / \mathrm{C} /[\mathrm{PVDF}-\mathrm{PVA}](25: 75)$ & 110 & 105 & - & [96] \\
\hline $\mathrm{LiMn}_{2} \mathrm{O}_{4} / \mathrm{C} /$ sodium alginate & - & 118 & - & [49] \\
\hline $\mathrm{LiMn}_{2} \mathrm{O}_{4} / \mathrm{C} / \mathrm{PVDF}$ & 122 & 115 & $92(3 \mathrm{C})$ & [72] \\
\hline $\mathrm{LiMn}_{2} \mathrm{O}_{4} / \mathrm{C} / \mathrm{CMC}$ & 130 & 110 & $85(3 \mathrm{C})$ & [72] \\
\hline $\mathrm{LiMn}_{2} \mathrm{O}_{4} / \mathrm{C} / \mathrm{PAA}$ (in NMP) & 128 & 110 & $82(3 \mathrm{C})$ & [72] \\
\hline $\mathrm{LiMn}_{2} \mathrm{O}_{4} / \mathrm{C} /$ polyacrylonitrile & 92 & 89 & - & [97] \\
\hline $\mathrm{LiMn}_{2} \mathrm{O}_{4} / \mathrm{C} / \mathrm{PEDOT}: \mathrm{PSS} / \mathrm{CMC}$ & 128 & 116 & 87 & [66] \\
\hline \multirow{2}{*}{ Anode Material Based on $\mathrm{Li}_{4} \mathrm{Ti}_{5} \mathrm{O}_{12}$} & \multicolumn{3}{|c|}{$Q_{\mathrm{LTO}}, \mathrm{mAh} \cdot \mathrm{g}^{-1}$} & \multirow{2}{*}{ Ref } \\
\hline & $0.2 \mathrm{C}$ & $1 \mathrm{C}$ & $10 \mathrm{C}$ & \\
\hline [Mesoporous $\mathrm{Li}_{4} \mathrm{Ti}_{5} \mathrm{O}_{12} / \mathrm{C}$ nanocomposites]/C/PVDF & 162 & 145 & 121 & [7] \\
\hline $\mathrm{Zr}$-doped $\mathrm{Li}_{4} \mathrm{Ti}_{5} \mathrm{O}_{12} / \mathrm{C} / \mathrm{PVDF}$ & - & 188 & 149 & [98] \\
\hline $\begin{array}{l}\text { [Surface-fluorinated } \mathrm{Li}_{4} \mathrm{Ti}_{5} \mathrm{O}_{12} \text { nanowires/rGO } \\
\text { composite]/C/PVDF }\end{array}$ & - & 167 & 133 & [99] \\
\hline$\left[\mathrm{Li}_{4} \mathrm{Ti}_{5} \mathrm{O}_{12}\right.$ coated by PANI $] / \mathrm{C} / \mathrm{PVDF}$ & 175 & 155 & 100 & [31] \\
\hline$\left[\mathrm{Li}_{4} \mathrm{Ti}_{5} \mathrm{O}_{12}\right.$ nanorods coated by PEDOT]/C/PVDF & 172 & 169 & 135 & [34] \\
\hline$\left[\mathrm{Li}_{4} \mathrm{Ti}_{5} \mathrm{O}_{12}\right.$ coated by PEDOT]/C/PVDF & 172 & 160 & 140 & [100] \\
\hline [ $\mathrm{Li}_{4} \mathrm{Ti}_{5} \mathrm{O}_{12} /$ PEDOT:PSS composites]/C/PVDF (0.1 C charge) & 174 & 170 & 161 & [37] \\
\hline$\left[\mathrm{Li}_{4} \mathrm{Ti}_{5} \mathrm{O}_{12}\right.$ coated by polythiophene]/C/PVDF & 170 & 167 & 140 & {$[32]$} \\
\hline $\mathrm{Li}_{4} \mathrm{Ti}_{5} \mathrm{O}_{12} / \mathrm{C} /$ sodium alginate & - & 152 & 135 & [50] \\
\hline $\mathrm{Li}_{4} \mathrm{Ti}_{5} \mathrm{O}_{12} / \mathrm{C} /[\mathrm{CMC}$-styrene butadiene rubber $]$ & 160 & 125 & 55 & [101] \\
\hline $\mathrm{Li}_{4} \mathrm{Ti}_{5} \mathrm{O}_{12} / \mathrm{C} /$ Acryl S020 & 180 & 170 & 120 & [102] \\
\hline $\mathrm{Li}_{4} \mathrm{Ti}_{5} \mathrm{O}_{12} / \mathrm{C} / \mathrm{CMC}$ & 165 & 150 & 60 & {$[71]$} \\
\hline $\mathrm{Li}_{4} \mathrm{Ti}_{5} \mathrm{O}_{12} / \mathrm{C} / \mathrm{CMC}$ & 148 & 134 & 118 & [103] \\
\hline $\mathrm{Li}_{4} \mathrm{Ti}_{5} \mathrm{O}_{12} / \mathrm{C} / \mathrm{CMC}$ & 160 & 145 & 78 & [104] \\
\hline $\mathrm{Li}_{4} \mathrm{Ti}_{5} \mathrm{O}_{12} / \mathrm{C} / \mathrm{CMC}$ & 165 & 150 & 110 & [105] \\
\hline $\mathrm{Li}_{4} \mathrm{Ti}_{5} \mathrm{O}_{12} / \mathrm{C} / \mathrm{PEDOT}$ :PSS/guar gum & 166 & 164 & 119 & [106] \\
\hline $\mathrm{Li}_{4} \mathrm{Ti}_{5} \mathrm{O}_{12} / \mathrm{C} / \mathrm{PEDOT}: \mathrm{PSS} / \mathrm{CMC}$ & 175 & 167 & 138 & [64] \\
\hline
\end{tabular}

In general, as follows from the analysis of results presented in Tables 2 and 3, the electrodes with aqueous binders (CMC and PEDOT:PSS/CMC) as a rule exhibited superior C-rate capability and long-term cycling stability than those with PVDF binder. However, the comparison of electrodes with CMC binder with electrodes with combined PEDOT:PSS/CMC binder showed better electrochemical performance of most electrodes with PEDOT:PSS/CMC binder, which is attributed to faster lithium ion diffusion kinetics and lower electrode polarizations.

When considering the data in Table 3 it should be taken into account that a comparison of quantitative parameters is sensitive to initial nature and morphology of active materials, their grain size, mass loading, and some other properties. The difference in specific capacity values of formally similar in composition electrodes also reflects the impact of the structure and properties of initial active material grains (size, morphology, core-shell structures, different carbon additives, etc.). Thus, a proper comparison of the results given in the literature should account for peculiarities of the experimental preparation of electrode mass and in this sense the comparison of data from different works is less 
reliable than the results of a comparative study of different binders obtained in similar conditions. Therefore, in our opinion, only works representing data on a comparative study of different electrode compositions produced from the same active material can be the answer about the advantages or disadvantages of binder components.

In this sense, the articles with comparative study of effect of binders are of interest. For instance, in [72], the electrochemical properties of $\mathrm{LiMn}_{2} \mathrm{O}_{4}$ cathodes with four different binders based on PVDF, $\mathrm{CMC}$, and polyacrylic acid (PAA) with NMP and water (10 $\mathrm{wt} \%$. by mass) are investigated. These results show that the $\mathrm{LiMn}_{2} \mathrm{O}_{4}$ cathode with PAA/CMC binder displays the best cycle performance among these four cathodes. The highest values of capacity $\left(131 \mathrm{mAh} \cdot \mathrm{g}^{-1}\right.$ at $\left.0.2 \mathrm{C}\right)$ are found for composition with CMC and PAA (in NMP) binders, while for the composition with PVDF a lower value (122 $\mathrm{mAh} \cdot \mathrm{g}^{-1}$ at $0.2 \mathrm{C}$ ) is obtained. However, with increase of current density, the capacity loss is more expressed for CMC-bound electrodes $\left(112 \mathrm{mAh} \cdot \mathrm{g}^{-1}\right.$ at $\left.1.0 \mathrm{C}\right)$ compared to PVDF $\left(115 \mathrm{mAh} \cdot \mathrm{g}^{-1}\right.$ at 1.0 C), and at $3.0 \mathrm{C}$ the capacities are $85 \mathrm{mAh} \cdot \mathrm{g}^{-1}$ for CMC and $92 \mathrm{mAh} \cdot \mathrm{g}^{-1}$ for PVDF. These results showing higher capacity loss of CMC-bound LMO electrodes with increase of charge-discharge rate are in agreement with those shown in Figure 7 (Section 3.3).

On the other hand, the observations for $\mathrm{LiNi}_{1 / 3} \mathrm{Mn}_{1 / 3} \mathrm{Co}_{1 / 3} \mathrm{O}_{2}$ cathode material [107] are quite the opposite. PVDF-bound electrode exhibits the highest discharge capacity at $0.1 \mathrm{C}$ rate, but in the range of $0.2-5 \mathrm{C}$ rates $\mathrm{CMC}$-bound electrode shows outstanding performance.

The comparison of data for LMO-based materials with different aqueous binders shows that LMO with PEDOT:PSS/CMC binder has higher capacities at 0.2 and $1 \mathrm{C}$ than LMO with sodium alginate [49], CMC [72], and polyacrylonitrile [97] binders. No data were found in the literature for LMO materials with aqueous binders for comparison at $10 \mathrm{C}$ current density. Using complicated synthetic approaches, creating complex materials [13], or using additives such as $\mathrm{LiNbO}_{3}$ [92] naturally have led to superior performance of electrodes, but in our opinion these approaches are more difficult than tuning electrode performance by introduction of a conductive binder.

It should also be noted that exceptional results have been achieved for the cathodes based on commercially available lithium iron phosphate (LFP) and CMC-Li as a water-soluble binder [61]. Compared with PVDF binder, the battery with CMC-Li as a binder retains $97.8 \%$ of initial reversible capacity after 200 cycles $\left(176 \mathrm{mAh} \cdot \mathrm{g}^{-1}\right)$-a value which is even beyond the theoretical specific capacity of LFP. The authors of [61] concluded that CMC-Li as a ion-conductive polymer can increase the contents of freely moving lithium ions in lithium-ion batteries and shorten the diffusion pathway to the cathode particle surface, which leads to enhancement of the charge-discharge processes.

In $[10,70]$, higher specific capacity values are found for the LFP-based electrodes with graphene additives and PVDF binder than for the LFP-based material with PEDOT:PSS/CMC binder (at 0.2 and $1.0 \mathrm{C}$ ). This effect is assigned to efficient structure of materials and contribution to capacity from graphene additives. At high currents $(5 \mathrm{C})$, where data are available, the highest specific capacity value is observed for LFP with PEDOT:PSS/CMC binder in comparison with alternative water-based binders.

In other cases presented in Table 3, the LFP electrodes with PEDOT:PSS/CMC binder exhibited, as a rule, higher specific capacities than those with CMC and PVDF binders, especially at increased current densities.

In [55], the electrochemical properties of carbon black-free $\mathrm{LiFePO}_{4}$ composite electrode with different amounts of PEDOT:PSS (6-16 wt. \%), which is accomplishing a dual role of a binder and conducting additive, are investigated. The optimal value of specific capacity $110 \mathrm{mAh} \cdot \mathrm{g}^{-1}$ (1.0 C) are obtained at $8 \mathrm{wt}$. \%. The authors concluded that only a thin layer of binder between LFP grains is effective due to moderate conductivity of binder. The results presented in [67] also support the conclusion that it is the thin-layer surface modification of active grains that plays a very important role in enhancement of the functional characteristics. 
The electrochemical performance of LFP cathode with CMC binder reported in $[40,108]$ also shows higher capacities and lower irreversible capacity losses compared to PVDF-bound cathodes.

In the case of LFMP-based materials, similar trends are observed with PEDOT:PSS/CMC binder: the highest specific capacity at high $\mathrm{C}$-rates, moderate values at $1 \mathrm{C}$ in comparison with carbon-modified grains and high values at low current density. It should be noted here that electrochemical properties of LFMP have a strong dependence on the ratio of Fe to Mn; different ratios may complicate the comparison of data.

LTO-based anode material with PEDOT:PSS/CMC binder has achieved the theoretical specific capacity value at $0.2 \mathrm{C}$ current, while another PEDOT-containing electrode composition [34] shows a bit lower value; comparable values are observed for most electrodes at 1-10 C current densities. Extremely high capacity value beyond the theoretical one $\left(188 \mathrm{mAh} \cdot \mathrm{g}^{-1}\right.$ at $\left.1 \mathrm{C}\right)$ is reported in [98] and explained by Zr-doping of LTO. Higher capacity value $\left(174 \mathrm{mAh} \cdot \mathrm{g}^{-1}\right)$ is also obtained in [37] for LTO/PEDOT:PSS composites with PVDF binder at low charge rate $(0.2 \mathrm{C})$ compared to LTO/PVDF $\left(166 \mathrm{mAh} \cdot \mathrm{g}^{-1}\right) . \mathrm{Li}_{4} \mathrm{Ti}_{5} \mathrm{O}_{12}$ with $\mathrm{CMC}$ binder [71] has good rate capability at 0.2 and $1 \mathrm{C}$, but the highest capacity value achieved for this composition at high current density $(10 \mathrm{C})$ is extremely low $\left(60 \mathrm{mAh} \cdot \mathrm{g}^{-1}\right)$.

The enhanced performance of CMC-bound electrodes is usually assigned to strong hydrogen bonds resulting from the interaction of the - $\mathrm{OH}$ groups with surface oxygen ions of active materials and lithium ions, which facilitate to transport of lithium ions along molecular chains $[61,71,104,105]$. It is also true in the case of combined PEDOT:PSS/CMC binder, where a similar conclusion on the mechanism of binder influence could be drawn.

As follows from the analysis of data presented, water-based binders such as CMC and PEDOT:PSS/CMC are more efficient than PVDF for the active materials with poor ionic conductivity. PVDF hinders the diffusion of lithium in the charge-discharge process of the battery, and reduces the electrochemical activity of electrode material. However, as presented results clearly show, the CMC binder often limits the rate capability of the electrode.

Concerning the mechanistic insights on the effects of binder's nature on the specific capacities, C-rate capability and cycling stability of the electrodes, the role of such components as conducting polymer PEDOT:PSS and carboxymethyl cellulose is highlighted as follows:

(1) PEDOT:PSS acts as an electronic/ionic conductive component, providing more conductive media between active grains with tight electrical contacts.

(2) CMC additive acts as a thickening agent with good ionic conductivity, improving material by adjustable porosity and wettability by electrolyte, which facilitate $\mathrm{Li}^{+}$ion movement.

(3) In addition, the presence of ionogenic groups in the binder components (such as CMC and PEDOT:PSS) can create an increased concentration of lithium ions around the active material particles, which can also contribute to more efficient mass transfer during the discharge process.

The advantages of the combined PEDOT:PSS/CMC binder are additionally supported by charge transfer kinetic aspects, which are investigated in many of the papers cited in Table 3. In particular, systematic impedance measurements are performed in [64-67] for the three discussed binders, and the data on the interfacial resistances and diffusion coefficients of $\mathrm{Li}^{+}$ions are evaluated. The comparison of kinetic parameters obtained for all investigated electrodes (LFP, LTO, LMO, and LFMP) with different binders reveals two main factors which are responsible for significant improvement of electrochemical performance of PEDOT:PSS/CMC bound electrodes. It is found that in the row of binders PVDF-CMC - PEDOT:PSS/CMC, a gradual decrease of interfacial charge transfer resistance and the increase of $\mathrm{Li}^{+}$apparent diffusion coefficient takes place [64-67]. 
For LFP electrodes, the decrease of interfacial charge transfer resistance and the increase of $\mathrm{Li}^{+}$ effective diffusion coefficient are observed in the row PEDOT:PSS/CMC $<$ CMC $<$ PVDF. For example, for LFP electrodes at fully discharged state, the values of interfacial resistance $R_{\text {int }}$ (the sum of $R_{S E I}$ (the resistance in the solid electrolyte interphase) and $R_{c t}$ (the charge transfer resistance)) are 715 (PVDF), 180 (CMC), and 56 Ohm (PEDOT:PSS/CMC). The decrease of Warburg constants $\sigma_{\mathrm{w}}$, which determine the values of the Warburg diffusion resistance, is also observed in this row: 203 (PVDF), 72 (CMC), and $44 \mathrm{Ohm} \mathrm{s}^{-1 / 2}$ (PEDOT:PSS/CMC). A similar tendency is observed for other electrode materials, such as LFMP [65], LTO [64] and LMO [66].

The mechanism of influence of conductive binder on the interfacial resistance and $\mathrm{Li}^{+}$ion transport is somewhat similar to the influence of carbon coating of active grains. As reported in many papers [64-67], the surface electronic conductivity of electrode materials is greatly enhanced by carbonization, which results in the lowering of interfacial resistance. The wrapping of active grains by conducting polymer PEDOT:PSS provides more reliable electrical contact between neighboring particles. In combination with ionic conductivity of both components of binder, it would greatly enhance the coupled electron and ion transfer at interface and $\mathrm{Li}^{+}$ion transport in pores around active grains.

To demonstrate the difference of non-conducting and conductive binders, the possible mechanism of electron and ion pathways in conductive binder is schematically presented in Figure 10.
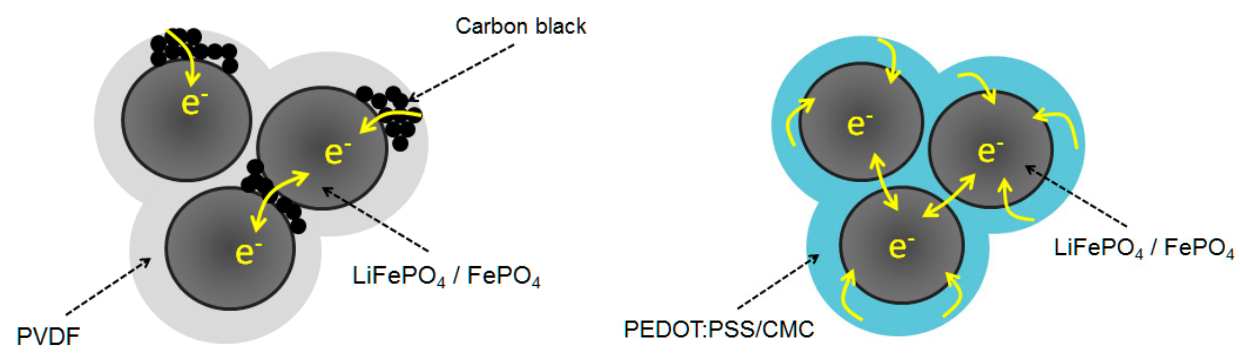

Figure 10. Electronic and ionic transport scheme for individual particles of active material in the media of PVDF and PEDOT:PSS/CMC [67].

The conductive polymer coating of active particles increases the electronic conductivity on the surface of an individual particle and reduces the transfer resistance of ionic and electronic charge. In the case of non-conducting PVDF binder, charge transfer occurs only in the region of point contact of active grains with carbon black particles (Figure 10).

In the case of a conductive polymer binder, charge transfer occurs over all the surface area of an active material particle that is in contact with the polymer. This contributes to a better electrical contact, uniform charge distribution and, accordingly, a more efficient and fast charge-discharge process. This effect is very similar in nature to the effect of a conductive carbon coating, which improves the surface conductivity of materials and significantly reduces polarization [19].

The employment of conductive binder formally enlarges the electric contact area and $\mathrm{Li}^{+}$diffusion cross-section area (Figure 11), thus decreasing diffusion resistance. Larger effective contact area means a greater probability to insert or drain $\mathrm{Li}^{+}$ions to/from the electrode. In addition, ionically conductive polymer coating also may facilitate ion transport around the active grains. It can be supposed that partly de-solvated $\mathrm{Li}^{+}$ions from polymer wrapping layer can be easily transmitted into the grain, providing an additional pathway for lithium ion insertion.

In this case, the polymer conductivity is described by the dynamic percolation model of ion transport, according to which lithium ions can diffuse through the polymer medium using segment motions of $-\mathrm{SO}_{3}$ groups that are associated with lithium ions (relay mechanism of lithium ion transfer) [109]. However, there is additional complexity, since this kind of conductivity is most often considered for systems where only the polymer is an ionic conductor. In the case, when the polymer 
is in contact with a liquid electrolyte, the ion transport can proceed not only due to the ion hopping from one ionic group to another, but also due to dissociation, solvation, and diffusion of the ion to the next group and association with it. Thus, in [110], it is shown for CMC, in contact with water, that the second mechanism of ion transport through dissociation and association is realized exactly the same. The nature of ion transport for the system considered in this paper is not yet fully understood and its clarification needs further research.

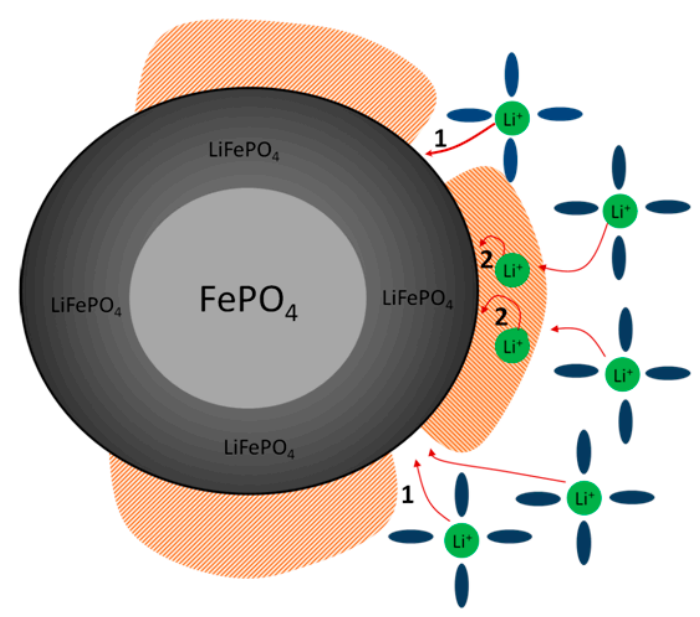

Figure 11. Diagram of ionic transport in an electrode material using a PEDOT:PSS/CMC binder. 1, ionic transport in polymer pores; 2 , ionic transport in the polymer.

\section{Summary}

Improved electrode materials for LIBs are in demand for different applications in power technologies. Enhanced specific capacities, C-rate capability, and cycle life of LIBs have been traditionally achieved via synthetic routes, e.g., synthesis of electrode materials with new structures or their modifications directed at improved charge-discharge properties. Recently, the wide choice of binders has offered the opportunity to improve the performance of energy storage materials, and design of binder compositions has become a trend in the development of LIB electrode materials.

In this review, the comparative analysis of effects of three different binders (PEDOT:PSS/CMC, $\mathrm{CMC}$, and PVDF) for a number of oxide-based and phosphate-based positive and negative electrodes for lithium-ion batteries is performed based on literature and our own published research data. It reveals that the combined PEDOT:PSS/CMC binder can be considered as a versatile component of lithium-ion battery electrode materials (for both positive and negative electrodes), effective in the wide range of electrode potentials. Special attention is paid to the comparison of the electrochemical properties of the electrodes with similar composition, fabricated with the use of the same in the origin active material powders and different binders. In this case, when the binder is the only variable component, the most reliable comparison of results can be performed.

Among the electrodes produced from four active materials (LFP, LFMP, LMO, and LTO) and three different binders, in most cases, all the electrodes with PEDOT:PSS/CMC conductive binder have shown superior properties in comparison with CMC-bound and PVDF-bound electrodes, in particular, increased specific capacity and good capacity retention. In particular, the use of PEDOT:PSS/CMC binder allows reducing the amount of inactive components, thus increasing the practical specific capacity. The advantages of PEDOT:PSS/CMC conductive binder were most expressed for high rate performance of $\mathrm{LiFe}_{0.4} \mathrm{Mn}_{0.6} \mathrm{PO}_{4}$ and $\mathrm{Li}_{4} \mathrm{Ti}_{5} \mathrm{O}_{12}$. Full battery test of electrodes with the same conductive binder composition and content ( $2 \mathrm{wt}$. \% of PEDOT:PSS and $2 \mathrm{wt}$ \% of CMC) produced from these materials demonstrated good cycling performance with capacity decay of only $16 \%$ over 1000 cycles. 
For most CMC-bound electrodes, the values of specific capacities at low current densities were higher than those for PVDF-bound electrodes and slightly worse or comparable with those of PEDOT:PSS/CMC bound electrodes, whereas both the high C-rate capability and the long-term cycling stability of PEDOT:PSS/CMC-bound electrodes were superior.

Concerning the mechanistic insights on the effects of binder's nature on the specific capacities, C-rate capability and cycling stability of the electrodes, the role of such components as conducting polymer PEDOT:PSS and carboxymethyl cellulose is highlighted as follows: (i) PEDOT:PSS acts as an electronic/ionic conductive component, providing more conductive media between active grains with tight electrical contacts; (ii) CMC additive acts as a thickening agent with good ionic conductivity, improving material by adjustable porosity and wettability by electrolyte, which facilitate $\mathrm{Li}^{+}$ion movement; and (iii) the presence of ionogenic groups in the binder components (such as CMC and PEDOT:PSS) can create an increased concentration of lithium ions around the active material particles, which can also contribute to more efficient mass transfer during the discharge process.

In addition, the advantages of combined PEDOT:PSS/CMC binder are confirmed by improved kinetics of charge transfer in the electrodes. In particular, the results of systematic impedance measurements revealed two main factors which are responsible for significant improvement of electrochemical performance of PEDOT:PSS/CMC-bound electrodes. In the row of binders PVDF-CMC—PEDOT:PSS/CMC, a gradual decrease of interfacial charge transfer resistance and the increase of $\mathrm{Li}^{+}$apparent diffusion coefficient, which facilitate to fast charge-discharge processes, are observed.

The combined conductive PEDOT:PSS/CMC binder can be considered as an efficient alternative to both the aqueous ion-conductive CMC binder and the non-conductive PVDF binder for commercial lithium-ion batteries. Easy one-step electrode preparation procedure makes composites of electroactive materials with PEDOT:PSS/CMC promising as industrial materials for lithium-ion batteries. In this review, we show a smart cost-effective approach for fabrication of LFP, LFMP, and LMO cathodes and LTO anodes from commercially available active materials for production of commercial LIBs with improved performance.

We believe that this mini-review, which summarizes the results of recent progress in application of PEDOT:PSS/CMC blend as a binder and conductive additive, will stimulate the researchers for search of new effective aqueous binder compositions and induce some new ideas in this field of research.

Author Contributions: Conceptualization, V.V.K.; Methodology, V.V.K. and S.N.E.; Investigation, M.A.K., S.N.E. and E.G.T.; Writing-Original Draft Preparation, V.V.K.; Writing-Review and Editing, S.N.E. and E.G.T.; Visualization, M.A.K. and E.G.T.; and Funding Acquisition, V.V.K. All authors have read and agreed to the published version of the manuscript.

Funding: This research was funded by St. Petersburg State University, grant number 26455158.

Acknowledgments: The authors are thankful to the colleagues from Interdisciplinary Resource centre for Nanotechnology of St. Petersburg State University.

Conflicts of Interest: The authors declare no conflict of interest.

\section{References}

1. Chou, S.L.; Pan, Y.; Wang, J.Z.; Liu, H.K.; Dou, S.X. Small things make a big difference: Binder effects on the performance of Li and Na batteries. Phys. Chem. Chem. Phys. 2014, 16, 20347-20359. [CrossRef] [PubMed]

2. Sengodu, P.; Deshmukh, A.D. Conducting polymers and their inorganic composites for advanced Li-ion batteries: A review. RSC Adv. 2015, 5, 42109-42130. [CrossRef]

3. Bresser, D.; Buchholz, D.; Moretti, A.; Varzi, A.; Passerini, S. Alternative binders for sustainable electrochemical energy storage-The transition to aqueous electrode processing and bio-derived polymers. Energy Environ. Sci. 2018, 11, 3096-3127. [CrossRef]

4. Chen, H.; Ling, M.; Hencz, L.; Ling, H.Y.; Li, G.; Lin, Z.; Liu, G.; Zhang, S. Exploring chemical, mechanical, and electrical functionalities of binders for advanced energy-storage devices. Chem. Rev. 2018, 118, 8936-8982. [CrossRef] [PubMed] 
5. Bruce, P.G.; Scrosati, B.; Tarascon, J.-M. Nanomaterials for rechargeable lithium batteries. Angew. Chem.-Int. Ed. 2008, 47, 2930-2946. [CrossRef] [PubMed]

6. Xu, B.; Qian, D.; Wang, Z.; Meng, Y.S. Recent progress in cathode materials research for advanced lithium ion batteries. Mater. Sci. Eng. R Rep. 2012, 73, 51-65. [CrossRef]

7. Shen, L.; Zhang, X.; Uchaker, E.; Yuan, C.; Cao, G. $\mathrm{Li}_{4} \mathrm{Ti}_{5} \mathrm{O}_{12}$ nanoparticles embedded in a mesoporous carbon matrix as a superior anode material for high rate lithium ion batteries. Adv. Energy Mater. 2012, 2, 691-698. [CrossRef]

8. Wang, G.X.; Yang, L.; Bewlay, S.L.; Chen, Y.; Liu, H.K.; Ahn, J.H. Electrochemical properties of carbon coated $\mathrm{LiFePO}_{4}$ cathode materials. J. Power Sources 2005, 146, 521-524. [CrossRef]

9. Deng, Z.; Wang, Q.; Peng, D.; Liu, H.; Chen, Y. Fast precipitation-induced $\mathrm{LiFe}_{0.5} \mathrm{Mn}_{0.5} \mathrm{PO}_{4} / \mathrm{C}$ nanorods with a fine size and large exposure of the (010) faces for high-performance lithium-ion batteries. J. Alloys Compd. 2019, 794, 178-185. [CrossRef]

10. Guan, Y.; Shen, J.; Wei, X.; Zhu, Q.; Zheng, X.; Zhou, S.; Xu, B. $\mathrm{LiFePO}_{4}$ activated carbon/graphene composite with capacitive-battery characteristics for superior high-rate lithium-ion storage. Electrochim. Acta 2019, 294, 148-155. [CrossRef]

11. Qi, M.; Liu, Y.; Xu, M.; Feng, M.; Gu, J.; Liu, Y.; Wang, L. Improved electrochemical performances of carbon-coated $\mathrm{LiFePO}_{4}$ microspheres for Li-ion battery cathode. Mater. Res. Express 2019, 6, 115520. [CrossRef]

12. Chen, Y.; Tian, Y.; Qiu, Y.; Liu, Z.; He, H.; Li, B.; Cao, H. Synthesis and superior cathode performance of sandwiched $\mathrm{LiMn}_{2} \mathrm{O}_{4} @ \mathrm{rGO}$ nanocomposites for lithium-ion batteries. Mater. Today Adv. 2019, 1, 100001. [CrossRef]

13. Li, L.; Sui, J.; Qin, W. Superior capacity, rate, long cycle life and high temperature performance of multilayered porous ultralong $\mathrm{LiMn}_{2} \mathrm{O}_{4}$ nanorods for lithium ion batteries. J. Electroanal. Chem. 2019, 833, 304-312. [CrossRef]

14. Yi, T.; Li, Y.; Fang, Z.; Cui, P.; Luo, S.; Xie, Y. Improving the cycling stability and rate capability of $\mathrm{LiMn}_{0.5} \mathrm{Fe}_{0.5} \mathrm{PO}_{4} / \mathrm{C}$ nanorod as cathode materials by $\mathrm{LiAlO}_{2}$ modification. J. Mater. 2020, 6, 33-44. [CrossRef]

15. Choi, D.; Wang, D.; Viswanathan, V.V.; Bae, I.T.; Wang, W.; Nie, Z.; Zhang, J.G.; Graff, G.L.; Liu, J.; Yang, Z.; et al. Li-ion batteries from $\mathrm{LiFePO}_{4}$ cathode and anatase/graphene composite anode for stationary energy storage. Electrochem. Commun. 2010, 12, 378-381. [CrossRef]

16. Shin, H.C.; Cho, W., II; Jang, H. Electrochemical properties of carbon-coated $\mathrm{LiFePO}_{4}$ cathode using graphite, carbon black, and acetylene black. Electrochim. Acta 2006, 52, 1472-1476. [CrossRef]

17. Yue, H.J.; Huang, X.K.; Lv, D.P.; Yang, Y. Hydrothermal synthesis of $\mathrm{LiMn}_{2} \mathrm{O}_{4} / \mathrm{C}$ composite as a cathode for rechargeable lithium-ion battery with excellent rate capability. Electrochim. Acta 2009, 54, 5363-5367. [CrossRef]

18. Jo, M.; Yoo, H.; Jung, Y.S.; Cho, J. Carbon-coated nanoclustered $\mathrm{LiMn}_{0.71} \mathrm{Fe}_{0.29} \mathrm{PO}_{4}$ cathode for lithium-ion batteries. J. Power Sources 2012, 216, 162-168. [CrossRef]

19. Mi, Y.; Gao, P.; Liu, W.; Zhang, W.; Zhou, H. Carbon nanotube-loaded mesoporousLiFe ${ }_{0.6} \mathrm{Mn}_{0.4} \mathrm{PO}_{4} / \mathrm{C}$ microspheres as high performance cathodes for lithium-ion batteries. J. Power Sources 2014, 267, 459-468. [CrossRef]

20. Lin, B.; Yin, Q.; Hu, H.; Lu, F.; Xia, H. $\mathrm{LiMn}_{2} \mathrm{O}_{4}$ nanoparticles anchored on graphene nanosheets as high-performance cathode material for lithium-ion batteries. J. Solid State Chem. 2014, 209, 23-28. [CrossRef]

21. Zhang, H.; Li, Z.; Yu, S.; Xiao, Q.; Lei, G.; Ding, Y. Carbon-encapsulated $\mathrm{LiMn}_{2} \mathrm{O}_{4}$ spheres prepared using a polymer microgel reactor for high-power lithium-ion batteries. J. Power Sources 2016, 301, 376-385. [CrossRef]

22. Chen, Y.; Zhang, H.; Li, Y.; Chen, Y.; Luo, T. Electrochemical performance of $\mathrm{Li}_{4} \mathrm{Ti}_{5} \mathrm{O}_{12} /$ carbon nanotubes/graphene composite as an anode material in lithium-ion batteries. Int. J. Hydrogen Energy 2017, 42, 7195-7201. [CrossRef]

23. Lin, Z.; Yang, Y.; Jin, J.; Wei, L.; Chen, W.; Lin, Y.; Huang, Z. Graphene-wrapped $\mathrm{Li}_{4} \mathrm{Ti}_{5} \mathrm{O}_{12}$ hollow spheres consisting of nanosheets as novel anode material for lithium-ion batteries. Electrochim. Acta 2017, 254, 287-298. [CrossRef]

24. Wang, G.X.; Yang, L.; Chen, Y.; Wang, J.Z.; Bewlay, S.; Liu, H.K. An investigation of polypyrrole-LiFePO 4 composite cathode materials for lithium-ion batteries. Electrochim. Acta 2005, 50, 4649-4654. [CrossRef]

25. Huang, Y.H.; Goodenough, J.B. High-rate $\mathrm{LiFePO}_{4}$ lithium rechargeable battery promoted by electrochemically active polymers. Chem. Mater. 2008, 20, 7237-7241. [CrossRef] 
26. Boyano, I.; Blazquez, J.A.; de Meatza, I.; Bengoechea, M.; Miguel, O.; Grande, H.; Huang, Y.; Goodenough, J.B. Preparation of $\mathrm{C}-\mathrm{LiFePO}_{4}$ /polypyrrole lithium rechargeable cathode by consecutive potential steps electrodeposition. J. Power Sources 2010, 195, 5351-5359. [CrossRef]

27. Wang, T.; Wang, W.; Zhu, D.; Huang, L.; Chen, Y. Improvement of the overall performances of $\mathrm{LiMn}_{2} \mathrm{O}_{4}$ via surface-modification by polypyrrole. Mater. Res. Bull. 2015, 71, 91-97. [CrossRef]

28. Fedorková, A.; Oriňáková, R.; Oriňák, A.; Talian, I.; Heile, A.; Wiemhöfer, H.D.; Kaniansky, D.; Arlinghaus, H.F. PPy doped PEG conducting polymer films synthesized on $\mathrm{LiFePO}_{4}$ particles. J. Power Sources 2010, 195, 3907-3912. [CrossRef]

29. Gong, C.; Deng, F.; Tsui, C.P.; Xue, Z.; Ye, Y.S.; Tang, C.Y.; Zhou, X.; Xie, X. PANI-PEG copolymer modified $\mathrm{LiFePO}_{4}$ as a cathode material for high-performance lithium ion batteries. J. Mater. Chem. A 2014, 2, 19315-19323. [CrossRef]

30. Lian, J.; Wang, X.; Zhang, W.; Huang, Y.; Xia, T.; Lian, Y. A ternary polyaniline/active carbon/lithium iron phosphate composite as cathode material for lithium ion battery. J. Nanosci. Nanotechnol. 2016, 16, 6494-6497. [CrossRef]

31. Hui, Y.; Cao, L.; Xu, Z.; Huang, J.; Ouyang, H.; Li, J.; Hu, H. In situ synthesis of core-shell $\mathrm{Li}_{4} \mathrm{Ti}_{5} \mathrm{O}_{12} @$ polyaniline composites with enhanced rate performance for lithium-ion battery anodes. J. Mater. Sci. Technol. 2017, 33, 231-238. [CrossRef]

32. $\mathrm{Xu}, \mathrm{D} . ;$ Wang, P.; Yang, R. Enhanced electrochemical performance of core-shell $\mathrm{Li}_{4} \mathrm{Ti}_{5} \mathrm{O}_{12} / \mathrm{PTh}$ as advanced anode for rechargeable lithium-ion batteries. Ceram. Int. 2017, 43, 7600-7606. [CrossRef]

33. Arbizzani, C.; Balducci, A.; Mastragostino, M.; Rossi, M.; Soavi, F. $\mathrm{Li}_{1.01} \mathrm{Mn}_{1.97} \mathrm{O}_{4}$ surface modification by poly(3,4-ethylenedioxythiophene). J. Power Sources 2003, 119-121, 695-700. [CrossRef]

34. Wang, X.; Shen, L.; Li, H.; Wang, J.; Dou, H.; Zhang, X. PEDOT coated $\mathrm{Li}_{4} \mathrm{Ti}_{5} \mathrm{O}_{12}$ nanorods: Soft chemistry approach synthesis and their lithium storage properties. Electrochim. Acta 2014, 129, 283-289. [CrossRef]

35. Cíntora-Juárez, D.; Pérez-Vicente, C.; Ahmad, S.; Tirado, J.L. Improving the cycling performance of $\mathrm{LiFePO}_{4}$ cathode material by poly(3,4-ethylenedioxythiopene) coating. RSC Adv. 2014, 4, 26108-26114. [CrossRef]

36. Vicente, N.; Haro, M.; Cíntora-Juárez, D.; Pérez-Vicente, C.; Tirado, J.L.; Ahmad, S.; Garcia-Belmonte, G. $\mathrm{LiFePO}_{4}$ particle conductive composite strategies for improving cathode rate capability. Electrochim. Acta 2015, 163, 323-329. [CrossRef]

37. Liu, Y.; Tang, D.; Zhong, H.; Zhang, Q.; Yang, J.; Zhang, L. Facile synthesis of nanostructured $\mathrm{Li}_{4} \mathrm{Ti}_{5} \mathrm{O}_{12}$ /PEDOT:PSS composite as anode material for lithium-ion batteries. RSC Adv. 2016, 6, 95512-95517. [CrossRef]

38. Maleki, H.; Deng, G.; Kerzhner-Haller, I.; Anani, A.; Howard, J.N. Thermal stability studies of binder materials in anodes for lithium-ion batteries. J. Electrochem. Soc. 2000, 147, 4470-4475. [CrossRef]

39. Liu, G.; Zheng, H.; Simens, A.S.; Minor, A.M.; Song, X.; Battaglia, V.S. Optimization of acetylene black conductive additive and PVDF composition for high-power rechargeable lithium-ion cells. J. Electrochem. Soc. 2007, 154, 1129-1134. [CrossRef]

40. Zaghib, K.; Striebel, K.; Guerfi, A.; Shim, J.; Armand, M.; Gauthier, M. LiFePO 4 /polymer/natural graphite: Low cost Li-ion batteries. Electrochim. Acta 2004, 50, 263-270. [CrossRef]

41. Li, J.; Christensen, L.; Obrovac, M.N.; Hewitt, K.C.; Dahn, J.R. Effect of heat treatment on Si electrodes using polyvinylidene fluoride binder. J. Electrochem. Soc. 2008, 155, A234-A238. [CrossRef]

42. Gören, A.; Costa, C.M.; Silva, M.M.; Lanceros-Méndez, S. State of the art and open questions on cathode preparation based on carbon coated lithium iron phosphate. Compos. Part B Eng. 2015, 83, 333-345. [CrossRef]

43. Li, J.-T.; Wu, Z.-Y.; Lu, Y.-Q.; Zhou, Y.; Huang, Q.-S.; Huang, L.; Sun, S.-G. Water soluble binder, an electrochemical performance booster for electrode materials with high energy density. Adv. Energy Mater. 2017, 7, 1701185. [CrossRef]

44. Lee, J.H.; Paik, U.; Hackley, V.A.; Choi, Y.M. Effect of carboxymethyl cellulose on aqueous processing of natural graphite negative electrodes and their electrochemical performance for lithium batteries. J. Electrochem. Soc. 2005, 152, 1763-1769. [CrossRef]

45. Park, H.; Lee, D.; Song, T. Synthesis of carboxymethyl cellulose lithium by weak acid treatment and its application in high energy-density graphite anode for Li-Ion batteries. Ind. Eng. Chem. Res. 2018, 57, 8895-8901. [CrossRef]

46. Liu, G.; Shen, X.; Ui, K.; Wang, L.; Kumagai, N. Influence of the binder types on the electrochemical characteristics of tin nanoparticle negative electrode for lithium secondary batteries. J. Power Sources 2012, 217, 108-113. [CrossRef] 
47. Bo, D.; Xuanning, H.; Zhenfei, C.; Yangzhou, M.; Guangsheng, S.; Weidong, Y.; Cuie, W. Effects of binders on electrochemical properties of high capacity silicon composite anodes. Inorg. Chem. Commun. 2020, 113, 107771. [CrossRef]

48. Huang, S.; Ren, J.; Liu, R.; Yue, M.; Huang, Y.; Yuan, G. The progress of novel binder as a non-ignorable part to improve the performance of Si-based anodes for Li-ion batteries. Int. J. Energy Res. 2018, 42, 919-935. [CrossRef]

49. Ryou, M.H.; Hong, S.; Winter, M.; Lee, H.; Choi, J.W. Improved cycle lives of $\mathrm{LiMn}_{2} \mathrm{O}_{4}$ cathodes in lithium ion batteries by an alginate biopolymer from seaweed. J. Mater. Chem. A 2013, 1, 15224-15229. [CrossRef]

50. De Giorgio, F.; La Monaca, A.; Dinter, A.; Frankenberger, M.; Pettinger, K.H.; Arbizzani, C. Water-processable $\mathrm{Li}_{4} \mathrm{Ti}_{5} \mathrm{O}_{12}$ electrodes featuring eco-friendly sodium alginate binder. Electrochim. Acta 2018, 289, 112-119. [CrossRef]

51. Zhang, L.; Chai, L.; Qu, Q.; Zhang, L.; Shen, M.; Zheng, H. Chitosan, a new and environmental benign electrode binder for use with graphite anode in lithium-ion batteries. Electrochim. Acta 2013, 105, 378-383.

52. He, J.; Wang, J.; Zhong, H.; Ding, J.; Zhang, L. Cyanoethylated carboxymethyl chitosan as water soluble binder with enhanced adhesion capability and electrochemical performances for $\mathrm{LiFePO}_{4}$ cathode. Electrochim. Acta 2015, 182, 900-907. [CrossRef]

53. Kim, J.M.; Park, H.S.; Park, J.H.; Kim, T.H.; Song, H.K.; Lee, S.Y. Conducting polymer-skinned electroactive materials of lithium-ion batteries: Ready for monocomponent electrodes without additional binders and conductive agents. ACS Appl. Mater. Interfaces 2014, 6, 12789-12797. [CrossRef] [PubMed]

54. Levin, O.V.; Eliseeva, S.N.; Alekseeva, E.V.; Tolstopjatova, E.G.; Kondratiev, V.V. Composite $\mathrm{LiFePO}_{4} /$ poly-3,4-ethylenedioxythiophene cathode for lithium-ion batteries with low content of non-electroactive components. Int. J. Electrochem. Sci. 2015, 10, 8175-8189.

55. Das, P.R.; Komsiyska, L.; Osters, O.; Wittstock, G. PEDOT:PSS as a functional binder for cathodes in lithium ion batteries. J. Electrochem. Soc. 2015, 162, A674-A678. [CrossRef]

56. Shkreba, E.V.; Eliseeva, S.N.; Apraksin, R.V.; Kamenskii, M.A.; Tolstopjatova, E.G.; Kondratiev, V.V. Electrochemical performance of lithium titanate anode fabricated using a water-based binder. Mendeleev Commun. 2019, 29, 105-107. [CrossRef]

57. Chiu, H.C.; Lu, X.; Zhou, J.; Gu, L.; Reid, J.; Gauvin, R.; Zaghib, K.; Demopoulos, G.P. Capacity fade mechanism of $\mathrm{Li}_{4} \mathrm{Ti}_{5} \mathrm{O}_{12}$ nanosheet anode. Adv. Energy Mater. 2016, 7, 1601825. [CrossRef]

58. Memm, M.; Hoffmann, A.; Wohlfahrt-Mehrens, M. Water-based $\mathrm{LiNi}_{1 / 3} \mathrm{Mn}_{1 / 3} \mathrm{Co}_{1 / 3} \mathrm{O}_{2}$-cathodes with good electrochemical performance by use of additives. Electrochim. Acta 2018, 260, 664-673. [CrossRef]

59. Cetinel, F.A.; Bauer, W. Processing of water-based $\mathrm{LiNi}_{1 / 3} \mathrm{Mn}_{1 / 3} \mathrm{Co}_{1 / 3} \mathrm{O}_{2}$ pastes for manufacturing lithium ion battery cathodes. Bull. Mater. Sci. 2014, 37, 1685-1690. [CrossRef]

60. Qiu, L.; Shao, Z.; Wang, W.; Wang, F.; Wang, D.; Zhou, Z.; Xiang, P.; Xu, C. Novel functional carboxymethyl cellulose lithium (CMC-Li) for enhanced performance of lithium-ion batteries. RSC Adv. 2014, 4, 24859-24862. [CrossRef]

61. Qiu, L.; Shao, Z.; Wang, D.; Wang, W.; Wang, F.; Wang, J. Enhanced electrochemical properties of LiFePO 4 (LFP) cathode using the carboxymethyl cellulose lithium (CMC-Li) as novel binder in lithium-ion battery. Carbohydr. Polym. 2014, 111, 588-591. [CrossRef] [PubMed]

62. Wang, Z.; Dupré, N.; Gaillot, A.C.; Lestriez, B.; Martin, J.F.; Daniel, L.; Patoux, S.; Guyomard, D. CMC as a binder in $\mathrm{LiNi}_{0.4} \mathrm{Mn}_{1.6} \mathrm{O}_{4} 5 \mathrm{~V}$ cathodes and their electrochemical performance for Li-ion batteries. Electrochim. Acta 2012, 62, 77-83. [CrossRef]

63. Chen, Z.; Kim, G.T.; Chao, D.; Loeffler, N.; Copley, M.; Lin, J.; Shen, Z.; Passerini, S. Toward greener lithium-ion batteries: Aqueous binder-based $\mathrm{LiNi}_{0.4} \mathrm{Co}_{0.2} \mathrm{Mn}_{0.4} \mathrm{O}_{2}$ cathode material with superior electrochemical performance. J. Power Sources 2017, 372, 180-187. [CrossRef]

64. Eliseeva, S.N.; Shkreba, E.V.; Kamenskii, M.A.; Tolstopjatova, E.G.; Holze, R.; Kondratiev, V.V. Effects of conductive binder on the electrochemical performance of lithium titanate anodes. Solid State Ionics 2019, 333, 18-29. [CrossRef]

65. Apraksin, R.V.; Eliseeva, S.N.; Kamenskii, M.A.; Tolstopyatova, E.G.; Lang, G.G.; Kondrat'ev, V.V. Impedance of $\mathrm{LiFe}_{0.4} \mathrm{Mn}_{0.6} \mathrm{PO}_{4}$ electrodes with combined conducting polymer binder of PEDOT:PSS and carboxymethyl cellulose. Russ. J. Electrochem. 2019, 55, 1047-1057. [CrossRef] 
66. Vorobeva, K.A.; Eliseeva, S.N.; Apraksin, R.V.; Kamenskii, M.A.; Tolstopjatova, E.G.; Kondratiev, V.V. Improved electrochemical properties of cathode material $\mathrm{LiMn}_{2} \mathrm{O}_{4}$ with conducting polymer binder. J. Alloys Compd. 2018, 766, 33-44. [CrossRef]

67. Eliseeva, S.N.; Apraksin, R.V.; Tolstopjatova, E.G.; Kondratiev, V.V. Electrochemical impedance spectroscopy characterization of $\mathrm{LiFePO}_{4}$ cathode material with carboxymethylcellulose and poly-3,4-ethylendioxythiophene/polystyrene sulfonate. Electrochim. Acta 2017, 227, 357-366. [CrossRef]

68. Apraksin, R.V.; Eliseeva, S.N.; Tolstopjatova, E.G.; Rumyantsev, A.M.; Zhdanov, V.V.; Kondratiev, V.V. High-rate performance of $\mathrm{LiFe}_{0.4} \mathrm{Mn}_{0.6} \mathrm{PO}_{4}$ cathode materials with poly(3,4-ethylenedioxythiopene): poly(styrene sulfonate)/carboxymethylcellulose. Mater. Lett. 2016, 176, 248-252. [CrossRef]

69. Eliseeva, S.N.; Levin, O.V.; Tolstopjatova, E.G.; Alekseeva, E.V.; Apraksin, R.V.; Kondratiev, V.V. New functional conducting poly-3,4-ethylenedioxythiopene:polystyrene sulfonate/carboxymethylcellulose binder for improvement of capacity of $\mathrm{LiFePO}_{4}$-based cathode materials. Mater. Lett. 2015, 161, 117-119. [CrossRef]

70. Shao, D.; Zhong, H.; Zhang, L. Water-soluble conductive composite binder containing PEDOT: PSS as conduction promoting agent for Si anode of lithium-ion batteries. ChemElectroChem 2014, 1, 1679-1687. [CrossRef]

71. Lee, B.R.; Oh, E.S. Effect of molecular weight and degree of substitution of a sodium-carboxymethyl cellulose binder on $\mathrm{Li}_{4} \mathrm{Ti}_{5} \mathrm{O}_{12}$ anodic performance. J. Phys. Chem. C 2013, 117, 4404-4409. [CrossRef]

72. Zhang, Z.; Zeng, T.; Lai, Y.; Jia, M.; Li, J. A comparative study of different binders and their effects on electrochemical properties of $\mathrm{LiMn}_{2} \mathrm{O}_{4}$ cathode in lithium ion batteries. J. Power Sources 2014, 247, 1-8. [CrossRef]

73. Du, G.; Xi, Y.; Tian, X.; Zhu, Y.; Zhou, Y.; Deng, C.; Zhu, H.; Natarajan, A. One-step hydrothermal synthesis of $3 \mathrm{D}$ porous microspherical $\mathrm{LiFePO}_{4} /$ graphene aerogel composite for lithium-ion batteries. Ceram. Int. 2019, 45, 18247-18254. [CrossRef]

74. Lepage, D.; Savignac, L.; Saulnier, M.; Gervais, S.; Schougaard, S.B. Modification of aluminum current collectors with a conductive polymer for application in lithium batteries. Electrochem. Commun. 2019, 102, 1-4. [CrossRef]

75. Lepage, D.; Michot, C.; Liang, G.; Gauthier, M.; Schougaard, S.B. A soft chemistry approach to coating of $\mathrm{LiFePO}_{4}$ with a conducting polymer. Angew. Chem.-Int. Ed. 2011, 50, 6884-6887. [CrossRef]

76. He, J.; Zhong, H.; Wang, J.; Zhang, L. Investigation on xanthan gum as novel water soluble binder for $\mathrm{LiFePO}_{4}$ cathode in lithium-ion batteries. J. Alloys Compd. 2017, 714, 409-418. [CrossRef]

77. Yang, S.; Huang, Y.; Su, S.; Han, G.; Liu, J. Hybrid humics/sodium carboxymethyl cellulose water-soluble binder for enhancing the electrochemical performance of a Li-ion battery cathode. Powder Technol. 2019, 351, 203-211. [CrossRef]

78. Lux, S.F.; Schappacher, F.; Balducci, A.; Passerini, S.; Winter, M. Low cost, environmentally benign binders for lithium-ion batteries. J. Electrochem. Soc. 2010, 157, A320. [CrossRef]

79. Qiu, L.; Shao, Z.; Wang, D.; Wang, F.; Wang, W.; Wang, J. Novel polymer Li-ion binder carboxymethyl cellulose derivative enhanced electrochemical performance for Li-ion batteries. Carbohydr. Polym. 2014, 112, 532-538. [CrossRef]

80. Kubarkov, A.V.; Drozhzhin, O.A.; Karpushkin, E.A.; Stevenson, K.J.; Antipov, E.V.; Sergeyev, V.G. Poly(3,4-ethylenedioxythiophene):poly(styrenesulfonic acid)-Polymer composites as functional cathode binders for high power $\mathrm{LiFePO}_{4}$ batteries. Colloid Polym. Sci. 2019, 297, 475-484. [CrossRef]

81. Hong, J.; Wang, F.; Wang, X.; Graetz, J. LiFe $\mathrm{Mn}_{1-\mathrm{x}} \mathrm{PO}_{4}$ : A cathode for lithium-ion batteries. J. Power Sources 2011, 196, 3659-3663. [CrossRef]

82. Hu, L.; Qiu, B.; Xia, Y.; Qin, Z.; Qin, L.; Zhou, X.; Liu, Z. Solvothermal synthesis of Fe-doping $\operatorname{LiMnPO}_{4}$ nanomaterials for Li-ion batteries. J. Power Sources 2014, 248, 246-252. [CrossRef]

83. Yan, S.Y.; Wang, C.Y.; Gu, R.M.; Li, M.W. Enhanced kinetic behaviors of $\mathrm{LiMn}_{0.5} \mathrm{Fe}_{0.5} \mathrm{PO}_{4} / \mathrm{C}$ cathode material by Fe substitution and carbon coating. J. Solid State Electrochem. 2015, 19, 2943-2950. [CrossRef]

84. Wang, Z.H.; Yuan, L.X.; Zhang, W.X.; Huang, Y.H. $\mathrm{LiFe}_{0.8} \mathrm{Mn}_{0.2} \mathrm{PO}_{4} / \mathrm{C}$ cathode material with high energy density for lithium-ion batteries. J. Alloys Compd. 2012, 532, 25-30. [CrossRef]

85. Ding, J.; Su, Z.; Tian, H. Synthesis of high rate performance $\mathrm{LiFe}_{1-\mathrm{x}} \mathrm{Mn}_{\mathrm{x}} \mathrm{PO}_{4} / \mathrm{C}$ composites for lithium-ion batteries. Ceram. Int. 2016, 42, 12435-12440. [CrossRef] 
86. Martha, S.K.; Grinblat, J.; Haik, O.; Zinigrad, E.; Drezen, T.; Miners, J.H.; Exnar, I.; Kay, A.; Markovsky, B.; Aurbach, D.; et al. $\mathrm{LiMn}_{0.8} \mathrm{Fe}_{0.2} \mathrm{PO}_{4}$ : An advanced cathode material for rechargeable lithium batteries. Angew. Chem.-Int. Ed. 2009, 48, 8559-8563. [CrossRef]

87. Xiong, J.; Wang, Y.; Wang, Y.; Zhang, J. PVP-assisted solvothermal synthesis of $\mathrm{LiMn}_{0.8} \mathrm{Fe}_{0.2} \mathrm{PO}_{4} / \mathrm{C}$ nanorods as cathode material for lithium ion batteries. Ceram. Int. 2016, 42, 9018-9024. [CrossRef]

88. Xiang, W.; Wu, Z.G.; Wang, E.H.; Chen, M.Z.; Song, Y.; Zhang, J.B.; Zhong, Y.J.; Chou, S.L.; Luo, J.H.; Guo, X.D.; et al. Confined synthesis of graphene wrapped $\mathrm{LiMn}_{0.5} \mathrm{Fe}_{0.5} \mathrm{PO}_{4}$ composite via two step solution phase method as high performance cathode for Li-ion batteries. J. Power Sources 2016, 329, 94-103. [CrossRef]

89. Saravanan, K.; Ramar, V.; Balaya, P.; Vittal, J.J. Li( $\left(\mathrm{Mn}_{\mathrm{x}} \mathrm{Fe}_{1-\mathrm{x}}\right) \mathrm{PO}_{4} / \mathrm{C}(\mathrm{x}=0.5,0.75$ and 1) nanoplates for lithium storage application. J. Mater. Chem. 2011, 21, 14925-14935. [CrossRef]

90. Zhou, X.; Xie, Y.; Deng, Y.; Qin, X.; Chen, G. The enhanced rate performance of $\mathrm{LiFe}_{0.5} \mathrm{Mn}_{0.5} \mathrm{PO}_{4} / \mathrm{C}$ cathode material via synergistic strategies of surfactant-assisted solid state method and carbon coating. J. Mater. Chem. A 2015, 3, 996-1004. [CrossRef]

91. Li, J.; Xiang, M.; Wang, Y.; Wu, J.; Zhao, H.; Liu, H. Effects of adhesives on the electrochemical performance of monodisperse $\mathrm{LiMn}_{0.8} \mathrm{Fe}_{0.2} \mathrm{PO}_{4} / \mathrm{C}$ microspheres as cathode materials for high power lithium-ion batteries. J. Mater. Chem. A 2017, 5, 7952-7960. [CrossRef]

92. Zhang, Z.J.; Chou, S.L.; Gu, Q.F.; Liu, H.K.; Li, H.J.; Ozawa, K.; Wang, J.Z. Enhancing the high rate capability and cycling stability of $\mathrm{LiMn}_{2} \mathrm{O}_{4}$ by coating of solid-state electrolyte $\mathrm{LiNbO}_{3}$. ACS Appl. Mater. Interfaces 2014, 6, 22155-22165. [CrossRef] [PubMed]

93. Han, C.G.; Zhu, C.; Saito, G.; Akiyama, T. Improved electrochemical performance of $\mathrm{LiMn}_{2} \mathrm{O}_{4}$ surface-modified by a $\mathrm{Mn}^{4+}$-rich phase for rechargeable lithium-ion batteries. Electrochim. Acta 2016, 209, 225-234. [CrossRef]

94. Fu, Y.; Jiang, H.; Hu, Y.; Dai, Y.; Zhang, L.; Li, C. Synergistic enhancement effect of Al doping and highly active facets of $\mathrm{LiMn}_{2} \mathrm{O}_{4}$ cathode materials for lithium-ion batteries. Ind. Eng. Chem. Res. 2015, 54, 3800-3805. [CrossRef]

95. Bhuvaneswari, S.; Varadaraju, U.V.; Gopalan, R.; Prakash, R. Structural stability and superior electrochemical performance of $\mathrm{Sc}$-doped $\mathrm{LiMn}_{2} \mathrm{O}_{4}$ spinel as cathode for lithium ion batteries. Electrochim. Acta 2019, 301, 342-351. [CrossRef]

96. Maazi, S.; Navarchian, A.H.; Khosravi, M.; Chen, P. Effect of poly (vinylidene fluoride)/poly (vinyl acetate) blend composition as cathode binder on electrochemical performances of aqueous Li-ion battery. Solid State Ionics 2018, 320, 84-91. [CrossRef]

97. Lee, S.; Kim, E.Y.; Lee, H.; Oh, E.S. Effects of polymeric binders on electrochemical performances of spinel lithium manganese oxide cathodes in lithium ion batteries. J. Power Sources 2014, 269, 418-423. [CrossRef]

98. Hou, L.; Qin, X.; Gao, X.; Guo, T.; Li, X.; Li, J. Zr-doped $\mathrm{Li}_{4} \mathrm{Ti}_{5} \mathrm{O}_{12}$ anode materials with high specific capacity for lithium-ion batteries. J. Alloys Compd. 2019, 774, 38-45. [CrossRef]

99. Hu, G.; Wu, J.; Du, K.; Peng, Z.; Jia, M.; Yang, H.; Cao, Y. Surface-fluorinated $\mathrm{Li}_{4} \mathrm{Ti}_{5} \mathrm{O}_{12}$ nanowires/reduced graphene oxide composite as a high-rate anode material for Lithium ion batteries. Appl. Surf. Sci. 2019, 479, 158-166. [CrossRef]

100. Zeng, Q.; $\mathrm{Wu}, \mathrm{J} . ; \mathrm{Yu}, \mathrm{Z}$.; Luo, L. Conductive PEDOT-decorated $\mathrm{Li}_{4} \mathrm{Ti}_{5} \mathrm{O}_{12}$ as next-generation anode material for electrochemical lithium storage. Solid State Ionics 2018, 325, 7-11. [CrossRef]

101. Wang, Z.; Xie, G.; Gao, L. Electrochemical characterization of $\mathrm{Li}_{4} \mathrm{Ti}_{5} \mathrm{O}_{12} / \mathrm{C}$ anode material prepared by starch-sol-assisted rheological phase method for Li-ion battery. J. Nanomater. 2012, 2012, 11-13. [CrossRef]

102. Pohjalainen, E.; Räsänen, S.; Jokinen, M.; Yliniemi, K.; Worsley, D.A.; Kuusivaara, J.; Juurikivi, J.; Ekqvist, R.; Kallio, T.; Karppinen, M.; et al. Water soluble binder for fabrication of $\mathrm{Li}_{4} \mathrm{Ti}_{5} \mathrm{O}_{12}$ electrodes. J. Power Sources 2013, 226, 134-139. [CrossRef]

103. Birrozi, A.; Copley, M.; von Zamory, J.; Pasqualini, M.; Calcaterra, S.; Nobili, F.; Cicco, A.D.; Rajantie, H.; Briceno, M.; Bilbé, E.; et al. Scaling up "Nano" $\mathrm{Li}_{4} \mathrm{Ti}_{5} \mathrm{O}_{12}$ for high-power lithium-ion anodes using large scale flame spray pyrolysis. J. Electrochem. Soc. 2015, 162, A2331-A2338. [CrossRef]

104. Chou, S.-L.; Wang, J.-Z.; Liu, H.-K.; Dou, S.-X. Rapid synthesis of $\mathrm{Li}_{4} \mathrm{Ti}_{5} \mathrm{O}_{12}$ microspheres as anode materials and its binder effect for lithium-ion battery. J. Phys. Chem. C 2011, 115, 16220-16227. [CrossRef]

105. Lee, B.; Kim, S.; Oh, E. Bio-derivative galactomannan gum binders for $\mathrm{Li}_{4} \mathrm{Ti}_{5} \mathrm{O}_{12}$ negative electrodes in lithium-ion batteries. J. Electrochem. Soc. 2014, 161, A2128-A2132. [CrossRef] 
106. Kamenskii, M.A.; Eliseeva, S.N.; Holze, R.; Kondratiev, V.V. Performance of negative lithium titanate electrodes containing minimized amounts of conducting polymer and modified guar gum as binder. J. Electrochem. Soc. 2019, 166, A3354-A3361. [CrossRef]

107. Xu, J.; Chou, S.L.; Gu, Q.F.; Liu, H.K.; Dou, S.X. The effect of different binders on electrochemical properties of $\mathrm{LiNi}_{1 / 3} \mathrm{Mn}_{1 / 3} \mathrm{Co}_{1 / 3} \mathrm{O}_{2}$ cathode material in lithium ion batteries. J. Power Sources 2013, 225, 172-178. [CrossRef]

108. Guerfi, A.; Kaneko, M.; Petitclerc, M.; Mori, M.; Zaghib, K. $\mathrm{LiFePO}_{4}$ water-soluble binder electrode for Li-ion batteries. J. Power Sources 2007, 163, 1047-1052. [CrossRef]

109. Ratner, M.A.; Shriver, D.F. Ion transport in solvent-free polymers. Chem. Rev. 1988, 88, 109-124. [CrossRef]

110. Casalegno, M.; Castiglione, F.; Passarello, M.; Mele, A.; Passerini, S.; Raos, G. Association and diffusion of $\mathrm{Li}^{+}$in carboxymethylcellulose solutions for environmentally friendly $\mathrm{Li}$-ion batteries. ChemSusChem 2016, 9, 1804-1813. [CrossRef]

(C) 2020 by the authors. Licensee MDPI, Basel, Switzerland. This article is an open access article distributed under the terms and conditions of the Creative Commons Attribution (CC BY) license (http://creativecommons.org/licenses/by/4.0/). 